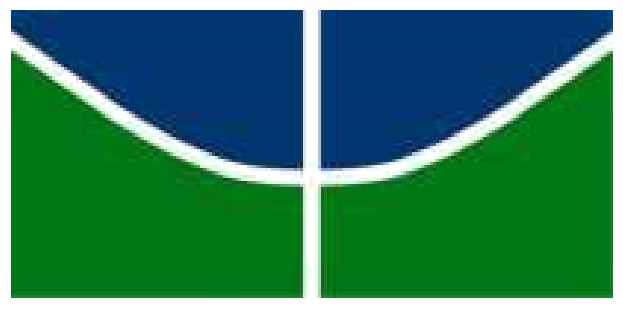

Universidade de Brasília Instituto de Ciências Biológicas Departamento de Biologia Celular Pós-Graduação em Biologia Molecular

\title{
Construção de cepas recombinantes de Saccharomyces cerevisiae para a produção de ramnolipídeos a partir de sacarose
}

Frederico Mendonça Bahia Silva

\author{
Brasília
}




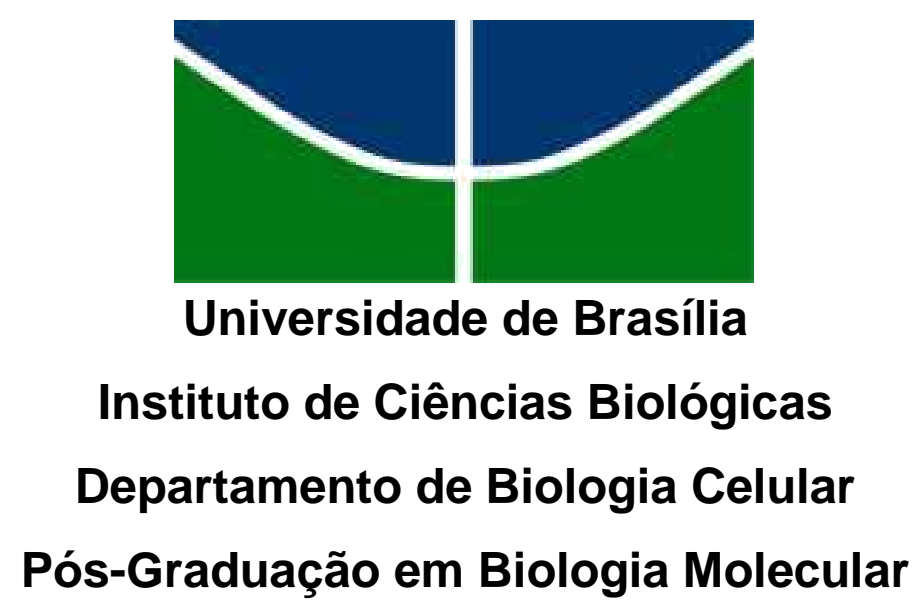

Frederico Mendonça Bahia Silva

Construção de cepas recombinantes de Saccharomyces cerevisiae para a produção de ramnolipídeos a partir de sacarose

Dissertação apresentada ao Departamento de Biologia Celular do Instituto de Ciências Biológicas da Universidade de Brasília como requisito parcial à obtenção do Título de Mestre em Biologia Molecular.

Orientadora: Prof. ${ }^{a}$ Dr.․ Nádia Skorupa Parachin

Brasília 
Trabalho desenvolvido no Laboratório de Biologia Molecular da Universidade de Brasília (UnB) sob a orientação da Prof. ${ }^{a}$ Dr. ㄹ Nádia Skorupa Parachin. 


\section{Banca Examinadora}

Presidente (orientadora):

Dr. Nádia Skorupa Parachin

Departamento de Biologia Celular (CEL/IB)

Universidade de Brasília - UnB

\section{Titulares:}

Dr. ${ }^{\text {a }}$ Eliane Ferreira Noronha

Departamento de Biologia Celular (CEL/IB)

Universidade de Brasília - UnB

Dr. aㅡ Talita Souza Carmo

Departamento de Biologia Celular (CEL/IB)

Universidade de Brasília - UnB

\section{Suplente:}

Dr. ${ }^{\text {a }}$ Ildinete Silva Pereira

Departamento de Biologia Celular (CEL/IB)

Universidade de Brasília - UnB 
"O saber deve ser como um rio, cujas águas doces, grossas, copiosas, transbordem do indivíduo, e se espraiem, estancando a sede dos outros. Sem um fim social, o saber será a maior das futilidades."

(Gilberto Freyre) 


\section{Agradecimentos}

Primeiramente agradeço à minha querida professora orientadora Nádia Parachin. Em seu primeiro semestre como professora da UnB já conheceu um aluno chato em uma de suas turmas de Bioquímica que, ao fim da disciplina, gostou tanto da professora que acabou a procurando para estagiar sob sua orientação. Cinco anos depois cá estou, fechando um período de muita aprendizagem, oportunidades e alguns puxões de orelha. Seus frequentes incentivos foram além de palavras bonitas, viabilizando muitas das minhas conquistas enquanto estudante. Muito obrigado por todo seu apoio e paciência professora, devo minha breve carreira profissional a você.

Agradeço à minha família que, mesmo receosa, apoiou minha decisão de mudar de graduação e sempre estabeleceu minha base financeira e emocional para que eu pudesse atingir os meus objetivos.

Aos meus queridos amigos, em especial David Lean, Gabriela Aguiar e Caio Catarcione, que fizeram com que minha nova vida em Brasília tomasse forma e sentido, sempre me escutando, aconselhando ou simplesmente me fazendo companhia. $\mathrm{O}$ apoio de vocês foi essencial para as minhas conquistas.

Um agradecimento mais que especial à Priscila Peres, minha queridíssima amiga e companheira de curso e laboratório, que agora é considerada parte da minha família. Sua amizade e cumplicidade foram cruciais em todos os aspectos da minha evolução enquanto pessoa e profissional.

Agradeço também aos meus colegas de laboratório, especialmente à Gabriela Carneiro, minha parceira de projeto. Sinto orgulho de como nosso grupo de trabalho é unido, amigável e prestativo. Um ambiente de trabalho saudável e colaborativo é essencial para o sucesso de cada um.

Aos meus colaboradores de projeto, em especial ao meu co-orientador Maurizio Bettiga, por toda a ajuda despendida, provendo robustez ao meu estudo e incrementando minha capacidade profissional.

Agradeço à UnB e a todos os professores que contribuíram para a minha formação profissional.

Por fim, agradeço aos órgãos de fomento CAPES e CNPq que viabilizaram financeiramente a execução do projeto. 


\section{Resumo}

Biossurfactantes são moléculas anfifilicas com propriedades tensoativas produzidas por diversos organismos. Ramnolipídeos são biossurfactantes glicolipídicos originalmente isolados do sobrenadante de culturas da bactéria patogênica Pseudomonas aeruginosa e são produzidos concomitantemente a fatores de virulência após sinalização por quorum sensing. São compostos de uma ou duas moléculas de ramnose (mono- ou di-ramnolipídeos, respectivamente) acoplada(s) a uma ou duas moléculas de ácido graxo, mais especificamente ácido betahidroxialcanoil-beta-hidroxialcanoico (HAA). Ramnolipídeos são alternativas ecologicamente viáveis aos surfactantes petroquímicos. Entretanto, ainda não foi atingida uma produção em escala industrial economicamente viável desses, principalmente devido a altos custos de substratos e processamento e baixos rendimentos e produtividades. Diante desse cenário, o presente trabalho objetivou a construção de cepas recombinantes de Saccharomyces cerevisiae para produção de ramnolipídeos a partir de sacarose. Para tal, seis enzimas responsáveis pela biossíntese de mono-ramnolipídeos em $P$. aeruginosa a partir de glicose-1-fosfato (RmIA, RmlB, RmlC, RmID, RhIA e RhIB) foram funcionalmente produzidas em Saccharomyces cerevisiae. Ademais, o gene SUC2 de levedura que codifica uma invertase foi interrompido e a enzima sacarose fosforilase de Pelomonas saccharophila foi também produzida na levedura.

Duas cepas foram construídas: a cepa produtora de mono-ramnolipídeos RLP e a cepa intermediária produtora de dTDP-L-ramnose RHP. A produção de ambas as moléculas foi confirmada por microscopia confocal e espectrometria de massa, respectivamente. As cepas engenheiradas com as vias de biossíntese de dTDP-Lramnose e mono-ramnolipídeos mostraram, pela primeira vez como prova de conceito, a produção dessas moléculas por um microrganismo eucariótico GRAS (do inglês, Generally Regarded As Safe) utilizando matéria-prima de baixo custo. Essas cepas mostram o potencial de continuar melhorando a produção de ramnolipídeos em bioprocesso industrial baseado em levedura para fazer com que se tornem um produto comercialmente competitivo globalmente. 


\section{Abstract}

Biosurfactants are biological surface-active amphiphilic agents produced by many microorganisms. Rhamnolipids are glycolipid biosurfactants originally isolated from the supernatant of Pseudomonas aeruginosa cultures and are concomitantly produced with virulence factors upon quorum sensing signaling. They are composed of one or two molecules of rhamnose (mono- or di-rhamnolipid, respectively) linked to one or two fatty acid molecules, more specifically beta-hydroxyalkanoyl-betahydroxyalkanoic acid (HAA). Rhamnolipids are green alternatives to petrochemical surfactants. However, their production has still not reached an economically feasible production in industrial scale, mainly due to high substrates and processing costs and low productivities and yields. With this in mind, this study aimed at the construction of recombinant $S$. cerevisiae strains for mono-rhamnolipids production from sucrose. Six enzymes responsible for mono-rhamnolipids biosynthesis in $P$. aeruginosa from glucose-1-phosphate (RmIA, RmIB, RmIC, RmID, RhIA and RhIB) were functionally expressed in Saccharomyces cerevisiae. Furthermore, the invertase encoding SUC2 gene from yeast was disrupted and the sucrose phosphorylase enzyme from Pelomonas saccharophila was also expressed in yeast.

Two strains were constructed: the mono-rhamnolipids production strain RLP and the intermediate dTDP-L-rhamnose producing strain RHP. Production of both molecules was confirmed by confocal microscopy and mass spectrometry, respectively. The engineered strains harboring biosynthesis pathways for dTDP-Lrhamnose and mono-rhamnolipids displayed, for the first time as a proof of concept, the production of these molecules by a GRAS eukaryotic microorganism using an inexpensive raw material. These constructs show the potential to further improve rhamnolipids production in a yeast-based industrial bioprocess to change rhamnolipids into a competitive global commodity. 


\section{Lista de Figuras}

Figura 1. As quatro estruturas químicas gerais de ramnolipídeos produzidos por algumas espécies de Pseudomonas. 19

Figura 2. Via metabólica de síntese de ramnolipídeos .20

Figura 3. Metabolismo de sacarose em Saccharomyces cerevisiae .26

Figura 4. Estratégia para aumentar rendimento de ATP por molécula de sacarose 27

Figura 5. Estratégia de clonagem .32

Figura 6. Estratégia de interrupção do gene SUC2. .34

Figura 7. PCR de confirmação da interrupção do gene SUC2 .45

Figura 8. Taxas de crescimento específico máximas ( $\mu$ máx) da cepa $\mathrm{RH} 1$ e sua cepa parental CEN.PK 102-3A .46

Figura 9. Atividades enzimáticas de $\mathrm{RmIA}$ para as cepas intermediárias $\mathrm{RH} 2$ e $\mathrm{RH} 4$ utilizando sacarose como substrato

Figura 10. Atividades enzimáticas de RmlA para as cepas intermediárias $\mathrm{RH} 2$ e $\mathrm{RH} 4$ utilizando glicose-1-fosfato como substrato.

Figura 11. Taxas de crescimento específico máximas ( $\left.\mu_{\text {máx }}\right)$ das cepas $R H R$ e RHP crescidas em sacarose na ausência e presença de LiCL 15mM. .50

Figura 12. Sobreposição dos resultados de MRM da cepa controle RHR (linha vermelha) e da cepa produtora RHP (linha preta). .53 
Figura 13. Análise de solução padrão de dTDP-L-ramnose (A), de extrato celular de RHP (B linha contínua) e de extrato celular de RHP adicionado de padrão de dTDPL-ramnose (B linha pontilhada).

Figura 14. Microscopias de fluorescência e contraste de fase das cepas RLR (A e B, respectivamente) e RLP (C e D, respectivamente). .58

Figura 15. Quantificação de células contendo gotículas lipídicas $(A)$ e de número de gotículas lipídicas por célula (B) das cepas RLR (referência) e RLP (produtora)......59

Figura 16. Quantificação do sinal de fluorescência. 60 


\section{Lista de Tabelas}

Tabela 1. Classificação estrutural dos surfactantes de origem microbiana

Tabela 2. Empresas produtoras de Ramnolipídeos

Tabela 3. Nome e tamanho dos genes, cassetes de expressão e plasmídeos utilizados nesse estudo.

Tabela 4. Iniciadores usados na amplificação de cassetes de expressão e na confirmação de construção de plasmídeos desse estudo.

Tabela 5. Iniciadores usados na amplificação do cassete de interrupção e na verificação da interrupção.

Tabela 6. Nome, genótipo relevante e cepa parental das cepas bacterianas utilizadas e produzidas nesse estudo

Tabela 7. Nome, genótipo relevante e cepa parental das cepas de levedura utilizadas e produzidas nesse estudo 37

Tabela 8. Resultado do ensaio de orcinol para detecção de RLs. 56 


\section{Lista de abreviaturas}

$\%$ : Por cento

oC: Graus Celsius

$\boldsymbol{\mu}$ : Taxa de crescimento específico

$\mu \mathbf{\mu g}$ : Micrograma

$\mu \mathrm{m}$ : Micrômetro

$\boldsymbol{\mu M}$ : Micromolar

3D: Tridimensional

Aa's: Aminoácidos

ADH: Gene para álcool desidrogenase

AGT1: Gene para transportador alfa-glucosidase

AmpR: Gene que confere resistência a ampicilina

ATP: Adenosina trifosfato

CMC: Concentração micelar crítica

Cmol: Moles de carbono

CSM: Mistura de Complemento e Suplemento

CYC: Gene para citocromo C

DIMS: Espectrometria de Massa de Infusão Direta

DNA: Ácido desoxirribonucleico

dTDP: Desoxitimidina difosfato

dTDP-Rha: dTDP-L-ramnose

dTTP: Desoxitimidina trifosfato

ESI(-)-MS: Espectrometria de Massa de Ionização por Eletrospray operado em Modo Negativo

EUA: Estados Unidos da América

FDA: Administração Federal de Alimentos e Medicamentos dos Estados Unidos

g: Grama

G: Força Centrífuga Relativa (RCF)

G418: Geneticina

Gft: Gene para sacarose fosforilase de Pelomonas saccharophila

G1P: Glicose-1-fosfato

G6P: Glicose-6-P 
GPD: Gene para gliceraldeído-3-fosfato desidrogenase

GRAS: Geralmente Reconhecido Como Seguro

h: Hora

HAA: Ácidos graxos beta-hidroxil

HCl: Ácido clorídrico

HPAEC: Cromatografia de Troca-Aniônica de Alta-Performance

HXT: Gene para transportador de hexose

KanMX: Gene híbrido de aminoglicosídeo transferase sob controle do promotor TEF usado como marca de seleção

Km: Constante de Michaelis-Menten

kg: Quilograma

L: Litro

LB: Meio Luria-Bertani

Leu: Leucina

LiCl: Cloreto de lítio

LUT: Lookup Table

m: Metro

m/z: Relação massa/carga

MALT: Gene para maltose permease

mg: Miligrama

$\mathrm{MgCL}_{2}$ : Cloreto de magnésio

$\mathrm{mL}$ : Mililitro

mm: Milímetro

mM: Milimolar

$\mathrm{mN}$ : Milinewton

MOPS: Ácido 3(N-morfolino)propanosulfônico

MRM: Monitoramento de Reações Múltiplas

MS: Espectrometria de Massa

MS/MS: Espectrometria de Massa em Tandem

$\mathbf{N}$ : Normal

$\mathrm{NaCl}$ : Cloreto de sódio

NaOH: Hidróxido de sódio

nm: Nanômetro

OD: Densidade ótica 
ORF: Fase Aberta de Leitura

p/v: Relação peso/volume

pAB: Plasmídeo p424TEF contendo cassetes de expressão de RhIA e RhIB pb: Pares de base pBD: Plasmídeo p426GPD contendo cassetes de expressão de RmIB e RmID PBS: Tampão Fosfato-Salino

PCR: Reação em cadeia da polimerase

PDA: Arranjo de fotodiodos

pGAC: Plasmídeo p425GPD contendo cassetes de expressão de Gft, RmIA e RmIC

PGM: Gene para fosfoglicomutase

pH: Potencial de hidrogênio

Pi: Fosfato inorgânico

Q: Quadrupolo

QS: Quorum sensing

$\mathbf{R}^{2}$ : Coeficiente de determinação

RL: Ramnolipídeo

RhIA: Gene para subunidade A de ramnosiltransferase1

RhIB: Gene para subunidade B de ramnosiltransferase1

RhIC: Gene para ramnosiltransferase2

RHP: Cepa Produtora de dTDP-L-ramnose

RHR: Cepa Referência de dTDP-L-ramnose

RLP: Cepa Produtora de mono-ramnolipídeos

RLR: Cepa Referência de mono-ramnolipídeos

RmIA: Gene para glicose-1-fosfato timidiltransferase

RmIB: Gene para dTDP-glicose 4,6-desidratase

RmIC: Gene para dTDP-4-desidroramnose 3,5-epimerase

RmID: Gene para dTDP-4-desidroramnose redutase

rpm: Rotações por minuto

SDS: Dodecil sulfato de sódio

SPE: Extração em Fase Sólida

SUC: Gene para invertases intra e extracelular

TEAA: Acetato de trietilamônia

TEF: Gene para fator de elongação translacional

Tm: Temperatura de denaturação 
Trp: Triptofano

UnB: Universidade de Brasília

UPLC: Cromatografia Líquida de Ultra Performance

Ura: Uracila

USD: Dólares norte-americanos

USDA: Departamento de Agricultura dos Estados Unidos

V: Volts

v/v: Relação volume/volume

YNB: Meio Base de Nitrogênio para Levedura

YPD: Meio Extrato de Levedura Peptona Dextrose 


\section{Sumário}

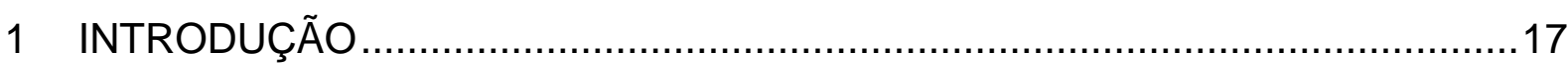

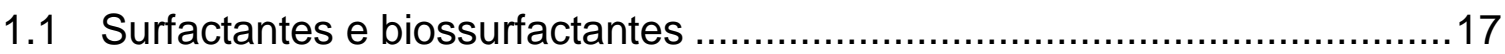

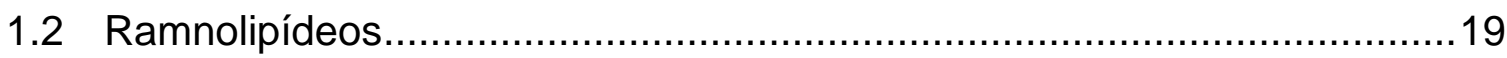

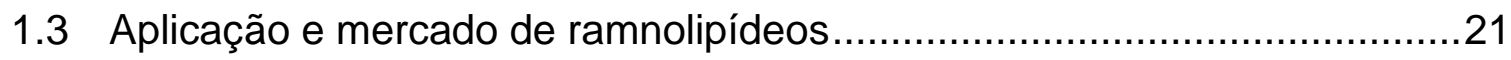

1.4 Sacarose como substrato para a produção de ramnolipídeos …................22

1.5 Engenharia metabólica para a produção de ramnolipídeos ………….......23

1.6 A levedura Saccharomyces cerevisiae .................................................24

1.7 Metabolismo de sacarose em Saccharomyces cerevisiae ........................25

2 JUSTIFICATIVA

3 OBJETIVOS

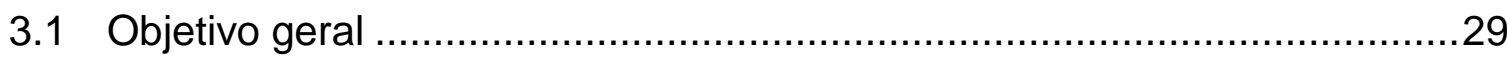

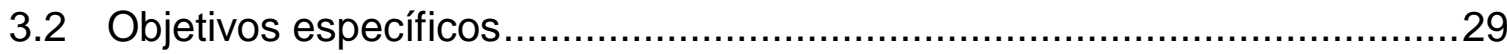

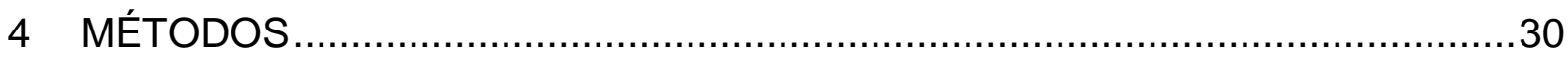

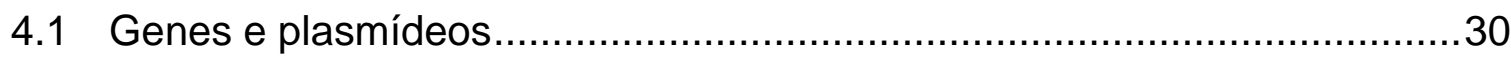

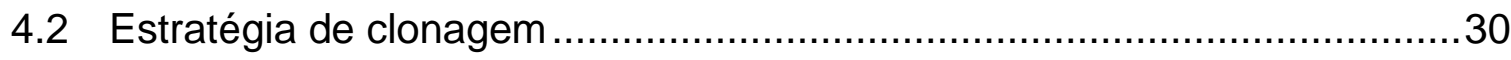

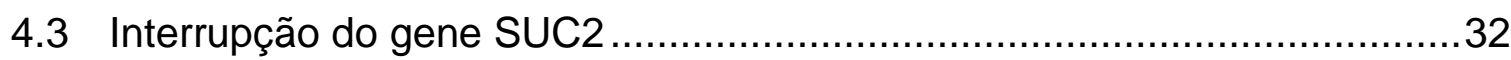

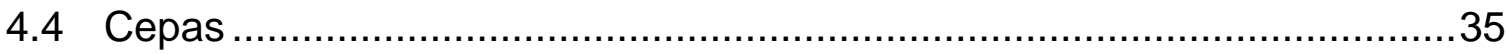

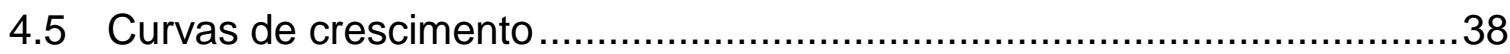

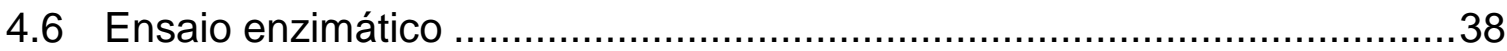

4.7 Análise de dTDP-L-ramnose ..............................................................39

4.7.1 Cromatografia de Troca-Aniônica de Alta-Performance....................39

4.7.2 Espectrometria de Massa em Tandem ........................................40

4.8 Análise de mono-ramnolipídeos ............................................................. 41

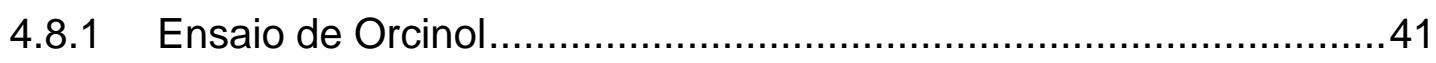

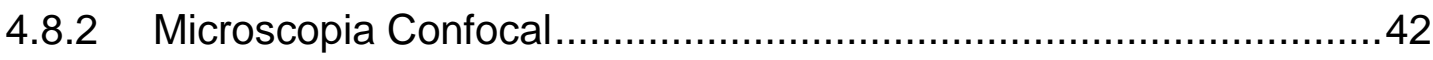




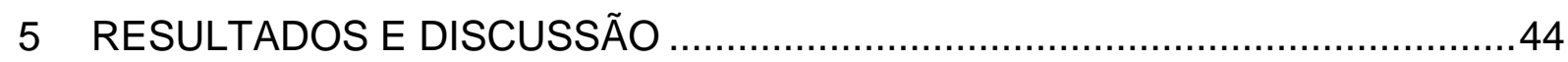

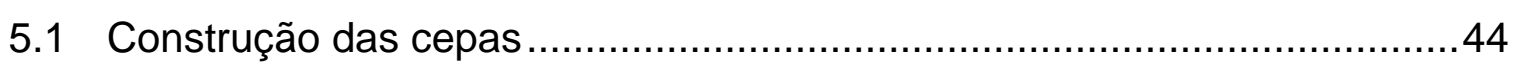

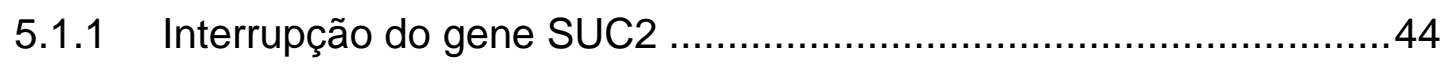

5.1.2 Análise de crescimento em sacarose...........................................45

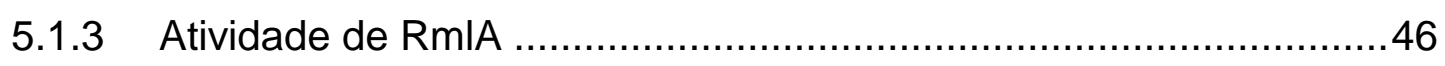

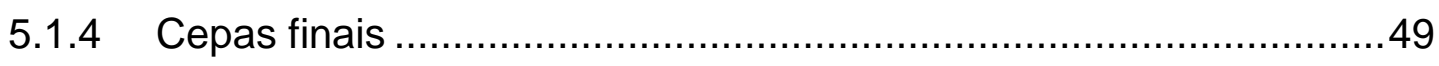

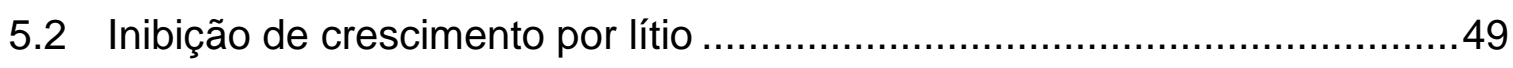

5.3 Deteç̧ão de dTDP-L-ramnose ............................................................

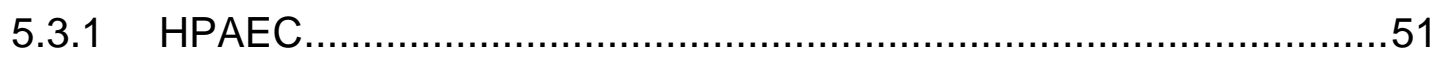

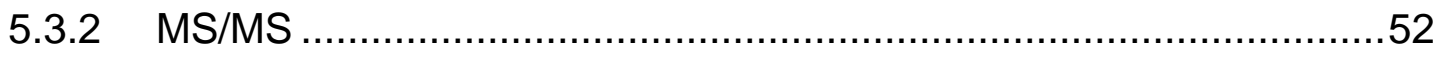

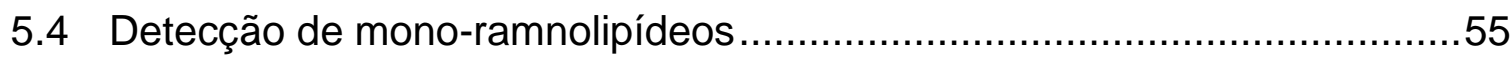

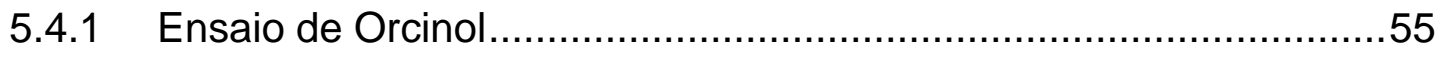

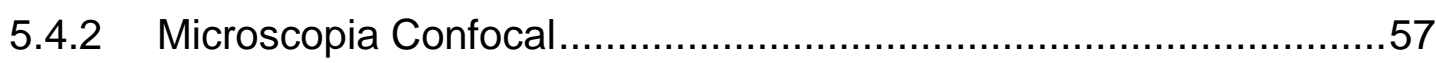

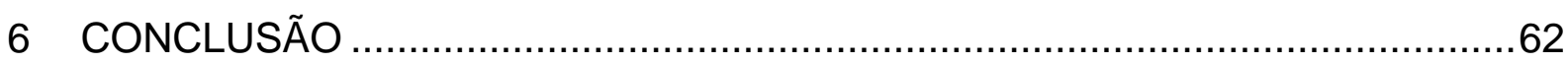

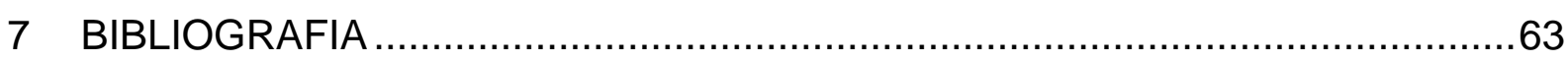




\section{INTRODUÇÃO}

\subsection{SURFACTANTES E BIOSSURFACTANTES}

Os surfactantes são uma importante classe de moléculas anfifílicas que facilitam a interação entre fases imiscíveis, reduzindo a tensão superficial ou interfacial entre elas. Com base nessa característica, a aplicação destas moléculas é extremamente ampla, já que possuem um grande poder de detergência, emulsificação, lubrificação, solubilização e dispersão. Podem ser utilizadas em diversos segmentos industriais, variando desde indústrias de produtos de limpeza até indústrias alimentícia e farmacêutica, além do uso em biorremediação no derramamento de petróleo (Henkel et al., 2012). A grande plasticidade no uso dessas moléculas em diversas frentes justifica sua demanda anual de aproximadamente 15 milhões de toneladas (Van Bogaert et al., 2007). Estimou-se que o mercado de surfactantes atingiria um valor de 30,64 bilhões USD em 2016, podendo chegar a atingir um valor de 39,86 bilhões USD em 2021. Esses valores se traduzem em um crescimento de 5,4\% ao ano, sendo a indústria de produtos de higiene pessoal e beleza a que mais impulsiona esse crescimento (Marketsandmarkets, 2016).

Surfactantes são classificados em dois principais grupos: surfactantes sintéticos e biossurfactantes. Surfactantes sintéticos são quimicamente produzidos e classificados de acordo com a natureza de seu grupo polar (Pornsunthorntawee et al., 2010). Apesar de serem os mais utilizados em escala industrial, são, em sua maioria, de origem petroquímica, uma fonte não renovável de recursos, e de difícil degradação, fato que as torna poluentes pelo longo tempo de residência em ambientes contaminados (Henkel et al., 2012).

Biossurfactantes, assim como os surfactantes sintéticos, são moléculas tensoativas, mas que, em contrapartida, são oriundas de fontes renováveis por meio do cultivo celular de microrganismos produtores, como bactérias e fungos (Müller et al., 2012; Pornsunthorntawee et al., 2010). Tais moléculas são muito diversas estruturalmente e são classificadas de acordo com o microrganismo produtor ou de 
acordo com sua natureza química estrutural (Tabela 1). Normalmente, o módulo hidrofóbico da molécula é composto por cadeias de ácidos graxos e o módulo polar é composto por moléculas de natureza diversa, e.g. carboidratos, ácidos carboxílicos, aminoácidos e até peptídeos cíclicos (Mulligan et al., 2001).

Tabela 1. Classificação estrutural dos surfactantes de origem microbiana (Müller et al., 2012).

Classe estrutural Exemplos

\begin{tabular}{ll}
\hline Glicolipídeos & $\begin{array}{l}\text { Soforolipideos, ramnolipídeos, lipídeos de } \\
\text { trealose }\end{array}$ \\
Lipopeptídeos/lipoaminoácidos & $\begin{array}{l}\text { Surfactina } \\
\text { Polímeros }\end{array}$ \\
Óleos/membranas & Fosfoínas \\
\hline
\end{tabular}

Biossurfactantes de origem microbiana possuem relevantes vantagens quando comparados aos surfactantes de origem petroquímica, ao passo que apresentam ação emulsificante comparável, baixa toxicidade, alta biodegradabilidade, biocompatibilidade e, alguns deles, atividade antimicrobiana que pode ser explorada para o desenvolvimento de novos medicamentos (Banat et al., 2000; Rodrigues et al., 2006). Ademais, biossurfactantes atuam melhor que surfactantes petroquímicos em condições atípicas de temperatura, salinidade e pH (Banat, 1995; Mulligan, 2005). Por conseguinte, essas moléculas possuem maior potencial de uso industrial, principalmente nas indústrias de fármacos, cosméticos e alimentos (Pornsunthorntawee et al., 2010). Porém, o alto custo de produção dessas moléculas ainda não permitiu que atingissem maior participação no mercado global. Novas estimativas mostram que a demanda mundial de biossurfactantes em 2013 foi de aproximadamente 344 mil toneladas, podendo chegar a quase 462 mil toneladas em 2020, atingindo uma movimentação financeira de 2,8 milhões USD em 2023 (Sekhon Randhawa e Rahman, 2014). Dentre todas as moléculas conhecidas de biossurfactantes, os ramnolipídeos (RLs), que pertencem à classe dos glicolipídeos, são as mais estudadas (Müller, 2012). 


\subsection{RAMNOLIPÍDEOS}

Ramnolipídeos são moléculas de biossurfactantes produzidas por algumas espécies de Pseudomonas (Cameotra e Makkar, 2004). Suas estruturas moleculares consistem em uma ou duas moléculas de dTDP-L-ramnose (dTDP-Rha), porção hidrofílica da molécula, ligadas a uma ou duas cadeias de ácido graxo $\beta$-hidroxil (HAA), porção hidrofóbica da molécula, sendo o número de carbonos da cadeia lipídica variável de 8 até 16 (Figura 1) (Abdel-Mawgoud et al., 2011).

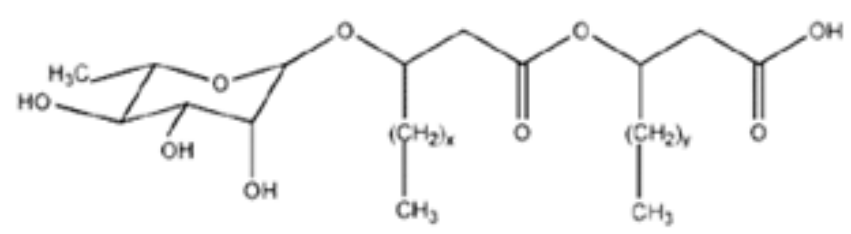

Rha-Cx-Cy

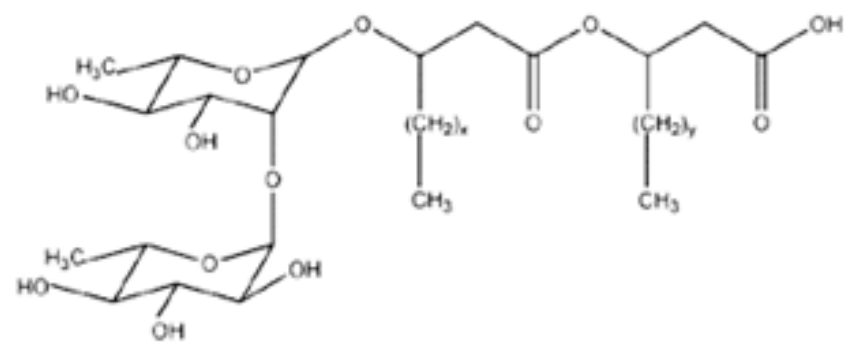

Rha-Rha-Cx-Cy

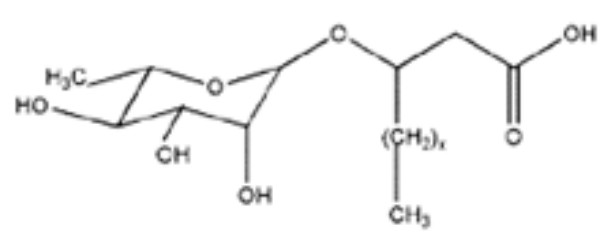

Rha-Cx

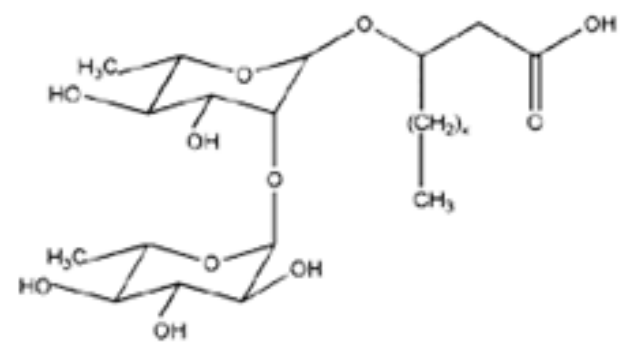

Rha-Rha-Cx

Figura 1. As quatro estruturas químicas gerais de ramnolipídeos produzidos por algumas espécies de Pseudomonas, sendo elas uma ou duas moléculas de dTDP-L-ramnose ligadas a uma ou duas moléculas de ácido graxo de cadeia carbônica de tamanhos variados (Modificada de Pornsunthorntawee et al., 2010).

Geralmente, ramnolipídeos são secretados como uma mistura heterogênea de moléculas (Pornsunthorntawee et al., 2010) e a síntese desses em P. aeruginosa se dá pela convergência de duas vias metabólicas, sendo a parte hidrofóbica proveniente da via de síntese de novo de ácidos graxos e a parte hidrofílica do operon RmIABCD (Figura 2) (Reis et al., 2011). Em maiores detalhes, a primeira via para produção de RLs se dá pela conversão do metabólito central D-glicose-1-fosfato em dTDP-Rha, feita pelas enzimas RmIA (Glicose-1-fosfato timidiltransferase), RmIB (dTDP-glicose 4,6-desidratase), RmIC (dTDP-4-desidroramnose 3,5-epimerase) e RmID (dTDP-4- 
desidroramnose redutase). As subunidades RhIA e RhlB formam a enzima ramnosiltransferase 1, responsável por desviar o intermediário beta-hidroxiacil-ACP da via de biossíntese de ácidos graxos de novo para sintetizar HAAs e então ligá-los a uma molécula de dTDP-Rha, resultando em mono-RLs. A enzima RhIC (ramnosiltransferase 2) é responsável por ligar mais uma molécula de dTDP-Rha a mono-RLs previamente sintetizados, resultando em di-RLs. (Reis et al., 2013).

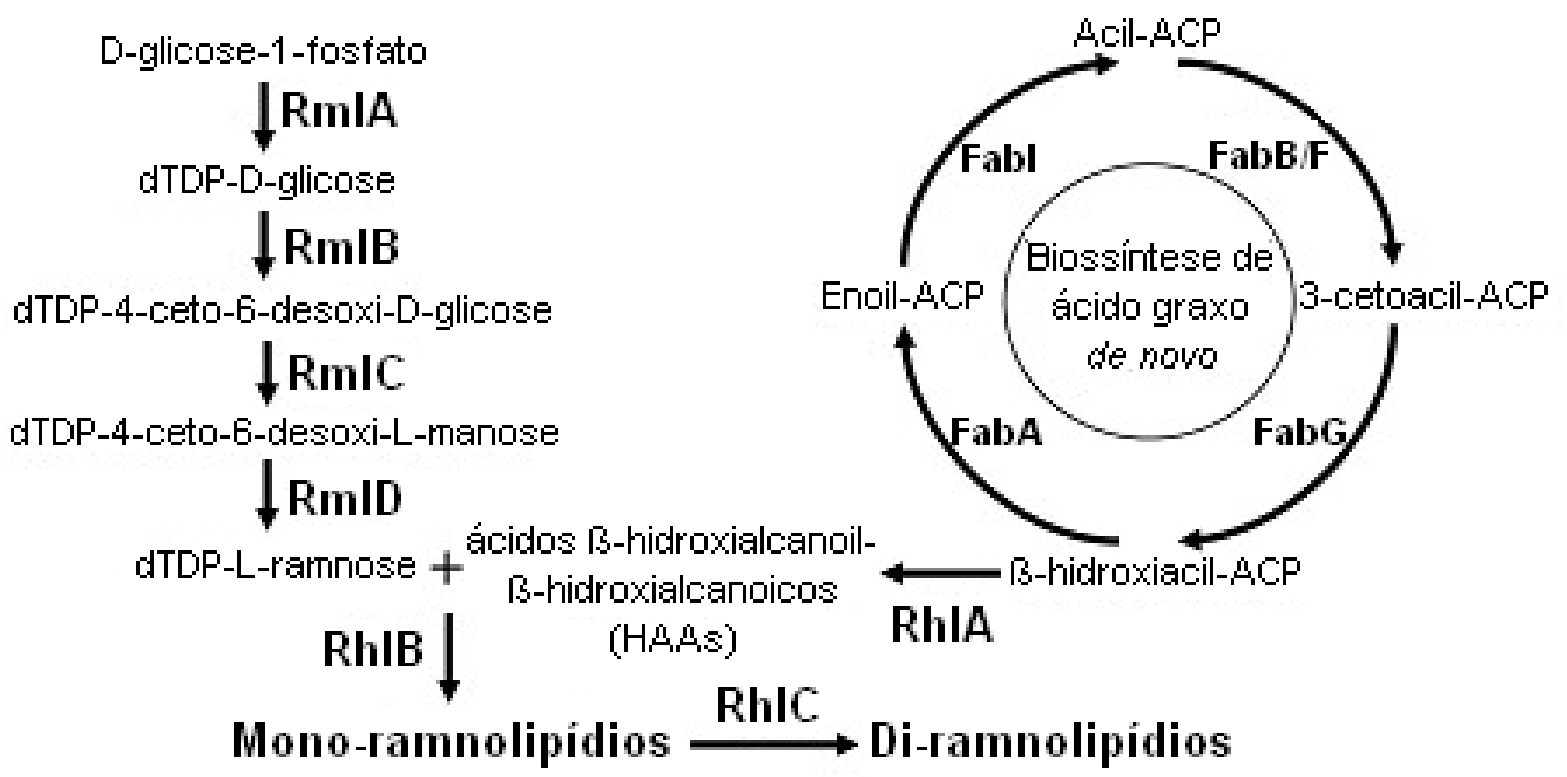

Figura 2. Via metabólica de síntese de ramnolipídeos (modificada de Gutierrez et al., 2013). As enzimas RmIA, RmIB, RmIC e RmID compõem a via de síntese de dTDP-L-ramnose à partir de D-glicose-1fosfato. A subunidade enzimática RhIA desvia o intermediário beta-hidroxiacil-ACP da via de biossíntese de ácidos graxos de novo para sintetizar HAAs, que são então ligados à dTDP-L-ramnose pelas subunidade enzimática RhIB e pela enzima RhIC, resultando em mono- e di-ramnolipídeos, respectivamente. 


\subsection{APLICAÇÃO E MERCADO DE RAMNOLIPÍDEOS}

Em comparação a outros biossurfactantes, os ramnolipídeos apresentam maior potencial de uso devido a propriedades comparáveis ou superiores às de surfactantes presentes no mercado. RLs e o detergente dodecil sulfato de sódio (SDS) possuem valores de atividade tensoativa e concentração micelar crítica (CMC) similares. Entretanto, apenas os RLs não desnaturam algumas das principais enzimas de uso industrial (Madsen et al., 2015; Syldatk et al., 1985; Fuguet et al., 2005). Além disso, são aprovados pela agência americana de regulamentação de alimentos e medicamentos (FDA) para uso na indústria alimentícia e já são comercializados, o que os torna mais competitivos dentre os biossurfactantes no mercado de surfactantes em geral (Reis et al., 2011; Pornsunthorntawee, 2010).

Atualmente, o custo estimado de produção biotecnológica de ramnolipídeos, em uma escala de 20 a $100 \mathrm{~m}^{3}$, varia de 5 a $20 \mathrm{USD} / \mathrm{kg}$, enquanto o custo da produção de surfactantes petroquímicos varia de 1 a 3 USD $/ \mathrm{kg}$ (Reis et al., 2011). Entretanto, o mercado global de biossurfactantes vem crescendo a uma taxa de 3,5\% ao ano. De acordo com dados recentes, este mercado valia 1,7 bilhões USD em 2011 e esperase que valha 2,2 bilhões USD em 2018 (Reis et al., 2013). Ainda há poucas empresas que produzem biossurfactantes em uma escala comercial, dentre as quais apenas seis, em sua maior parte norte americanas, comercializam RLs (Tabela 2) (Sekhon Randhawa \& Rahman, 2014). O preço de mercado dessas moléculas varia de 200 USD $/ \mathrm{kg}$ (solução a 20\%) a 6000 USD/kg (98\% puro) (Leitermann et al., 2010).

O tímido número de empresas que produzem e comercializam RLs é resultado de processos industriais dispendiosos, principalmente devido a baixos rendimentos dos processos fermentativos aliados a altos custos de substrato e purificação (Reis et al., 2013). Por serem produzidos concomitantemente a fatores de virulência, o processo de purificação deve ser minucioso a fim de evitar contaminação do produto final, o que encarece o processo como um todo. De fato, o processo de purificação é responsável por 70 a $80 \%$ do custo total de produção de RLs (Sekhon Randhawa \& Rahman, 2014). Assim, atualmente as pesquisas científicas estão focadas em diminuir custos de substrato, aumentar parâmetros fermentativos (e.g. rendimento e 
produtividade) e na produção heteróloga de RLs para contornar a complexa rede regulatória e a virulência da $P$. aeruginosa (Reis et al., 2013).

Tabela 2. Empresas produtoras de Ramnolipídeos (Sekhon Randhawa e Rahman, 2014).

\begin{tabular}{|c|c|c|}
\hline Empresa & Localização & Aplicação \\
\hline TeeGene Biotech & Reino Unido & $\begin{array}{l}\text { Indústria farmacêutica, cosméticos e } \\
\text { antimicrobianos }\end{array}$ \\
\hline $\begin{array}{l}\text { AGAE Technologies } \\
\text { LLC }\end{array}$ & EUA & $\begin{array}{l}\text { Indústria farmacêutica, cosméticos, } \\
\text { cuidado pessoal e biorremediação }\end{array}$ \\
\hline $\begin{array}{l}\text { Jeneil Biosurfactant } \\
\text { Co. LLC }\end{array}$ & EUA & Produtos de limpeza e biorremediação \\
\hline $\begin{array}{l}\text { Paradigm Biomedical } \\
\text { Inc. }\end{array}$ & EUA & Indústria farmacêutica \\
\hline $\begin{array}{l}\text { Rhamnolipid } \\
\text { Companies, Inc }\end{array}$ & EUA & $\begin{array}{l}\text { Indústria farmacêutica, alimentos, } \\
\text { cosméticos, biorremediação e agricultura }\end{array}$ \\
\hline Henkel & Alemanha & Produtos de limpeza e cosméticos \\
\hline
\end{tabular}

\subsection{SACAROSE COMO SUBSTRATO PARA A PRODUÇÃO DE RAMNOLIPÍDEOS}

A utilização de substratos de baixo custo, tais como resíduos industriais ou substratos renováveis, atualmente são pré-requisitos para a implementação de um bioprocesso economicamente viável (Reis et al., 2013). Diversos substratos já foram testados como fonte de carbono, como por exemplo diesel (Noh et al., 2014), glicose (Wittgens et al., 2011), óleo de girassol (Müller et al., 2011; Schmidberger et al., 2013), ácido oleico (Cabrera-Valladares et al., 2006), dentre outros. Entretanto, ainda não foi estabelecida uma estratégia de produção com rendimentos e produtividades economicamente competitivos.

Levando em consideração o atual cenário mundial de crescente preocupação ambiental e redução da dependência petroquímica, as biomassas de fontes renováveis aparecem como alternativas economicamente atrativas para produção de biocombustíveis e insumos básicos para suprir as indústrias químicas. Há muitos 
anos, o estudo da sacarose como matéria-prima para a produção de insumos para a indústria química e a produção de novos derivados com maior valor agregado tem despertado o interesse dos pesquisadores e de políticas específicas para este setor. Esse ramo da química é tão importante que passou a ser conhecido como sucroquímica, que é entendida como o ramo da ciência e da tecnologia cujo objetivo é acrescentar ao mercado novas utilizações da sacarose. Comparativamente, o baixo custo, a disponibilidade e a pureza fazem com que esta matéria-prima seja extensivamente vantajosa para novos processos industriais (Ferreira et al., 2009). Departamento de Agricultura dos EUA (USDA) apontou, em 2015, que o Brasil é o maior produtor e exportador de açúcar do mundo e que sua produção mundial é maior que o seu consumo. Isto revela a abundância deste produto no mercado, reduzindo seu custo.

Os fatos supramencionados corroboram a afirmação de que a sacarose é um potencial substrato na produção de ramnolipídeos ao visar diminuir os custos de produção.

\subsection{ENGENHARIA METABÓLICA PARA A PRODUÇÃO DE RAMNOLIPÍDEOS}

Além do custo do substrato, outros parâmetros como rendimento e produtividade de ramnolipídeos são importantes no estabelecimento de um processo economicamente viável. Dificilmente é encontrado um microrganismo que reúna todas as características desejadas para que um determinado metabólito seja produzido. Assim, o objetivo da engenharia metabólica é modificar ou adicionar vias metabólicas com o uso de técnicas de biologia molecular para obtenção de um produto específico (Bailey, 1991).

Diversos microrganismos já foram alvo de engenharia metabólica para produção de RLs, dentre eles a própria $P$. aeruginosa. Entretanto, uma complexa rede regulatória por trás da biossíntese de RLs por esta bactéria constitui um grande obstáculo para o escalonamento da produção. Para tentar elucidar os mecanismos metabólicos e moleculares envolvidos na síntese desses compostos, Schmidberger et al. (2013) monitoraram a expressão do operon RhIAB durante uma fermentação em 
batelada utilizando a cepa laboratorial $P$. aeruginosa PAO1 como biocatalisador. Demonstraram que esse operon tem expressão regulada durante o processo de fermentação, estando sob influência de mecanismos de quorum sensing (QS) e coexpressão com fatores de virulência.

Devido às complicações supracitadas, a transferência dos genes para outros microrganismos surge como uma estratégia que potencialmente auxilia no escalonamento da produção de RLs. Alguns microrganismos já foram modificados para produção de RLs, como Escherichia coli, Pseudomonas putida, Acinetobacter calcoaceticus, Enterobacter asburiae e Burkholderia thailandensis (Paulino et al., 2016). O maior rendimento reportado até o momento para cepas recombinantes é de 0,23 Cmolrss/Cmolsubstrato por Pseudomonas putida utilizando glicose como substrato, abaixo do rendimento de $0,33 \mathrm{Cmol}$ Lss/Cmolsubstrato atingido por $P$. aeruginosa (Wittgens et al., 2011).

\subsection{A LEVEDURA SACCHAROMYCES CEREVISIAE}

A levedura Saccharomyces cerevisiae é amplamente utilizada para produção de cerveja, pão, vinho, bioetanol, químicos e produtos nutracêuticos e farmacêuticos. As vantagens dessa levedura como hospedeira para produção heteróloga incluem: (i) possui status GRAS (do inglês Generally Regarded as Safe), o que facilita processos de descarte de resíduos e aprovação de produtos e processos; (ii) tolerância a baixo $\mathrm{pH}$, o que garante baixo risco de contaminação bacteriana e elimina a necessidade de neutralizar produtos ácidos; e (iii) tolerância a inibidores fermentativos, como os presentes em hidrolisados de biomassa (Borodina \& Nielsen, 2014). Outros fatores, como ferramentas genéticas e processos fermentativos industriais bem estabelecidos, levam a uma grande aceitação desta levedura no estabelecimento de novos bioprocessos.

Como exemplos de processos já estabelecidos e em escala comercial utilizando $S$. cerevisiae podem-se citar produção do precursor de droga anti-malária amorfadieno (Amyris), vanilina (Evolva), antioxidante resveratrol (Fluxome), polímero poli-ácido lático (NatureWorks), polietileno verde à partir de cana-de-açúcar via 
bioetanol (Braskem) e ácido succínico (Reveredia), dentre vários outros (Borodina \& Nielsen, 2014).

A S. cerevisiae não produz RLs e até o momento não foi documentada uma estratégia de produção heteróloga deste composto nesta levedura. Levando em consideração que a sacarose será utilizada como substrato, essa estratégia é vantajosa por permitir a utilização de um substrato de baixo custo para produção de composto de alto valor agregado por um microrganismo já adaptado a condições industriais.

\subsection{METABOLISMO DE SACAROSE EM SACCHAROMYCES CEREVISIAE}

Em S. cerevisiae, o metabolismo de sacarose é iniciado pela hidrólise em glicose e frutose realizada pelas enzimas invertase, uma extracelular e uma intracelular. Essas enzimas são codificadas pelos genes da família SUC, sendo o gene SUC2 o mais comum estando presente em todas as linhagens de $S$. cerevisiae (Grossmann e Zimmermann, 1979; Naumov et al., 1996). As duas formas pelas quais a utilização da sacarose se dá na levedura são as seguintes (Figura 3): na primeira, a invertase extracelular hidrolisa a sacarose em glicose e frutose no ambiente extracelular e a célula internaliza os monossacarídeos por meio de transportadores de hexose (HXT). Na segunda, a sacarose é internalizada ativamente por meio do transportador codificado pelo gene AGT1 ou pelo transportador MALT e depois hidrolisada no ambiente intracelular. Nesse caso, a hidrólise intracelular da sacarose pode ser feita por duas principais enzimas, a maltase ( $\alpha$-D-glicosidase) e a invertase intracelular ( $\beta$-D-frutosidase) (Mwesigye e Barford, 1996; Batista et al., 2004; Badotti et al., 2008). 


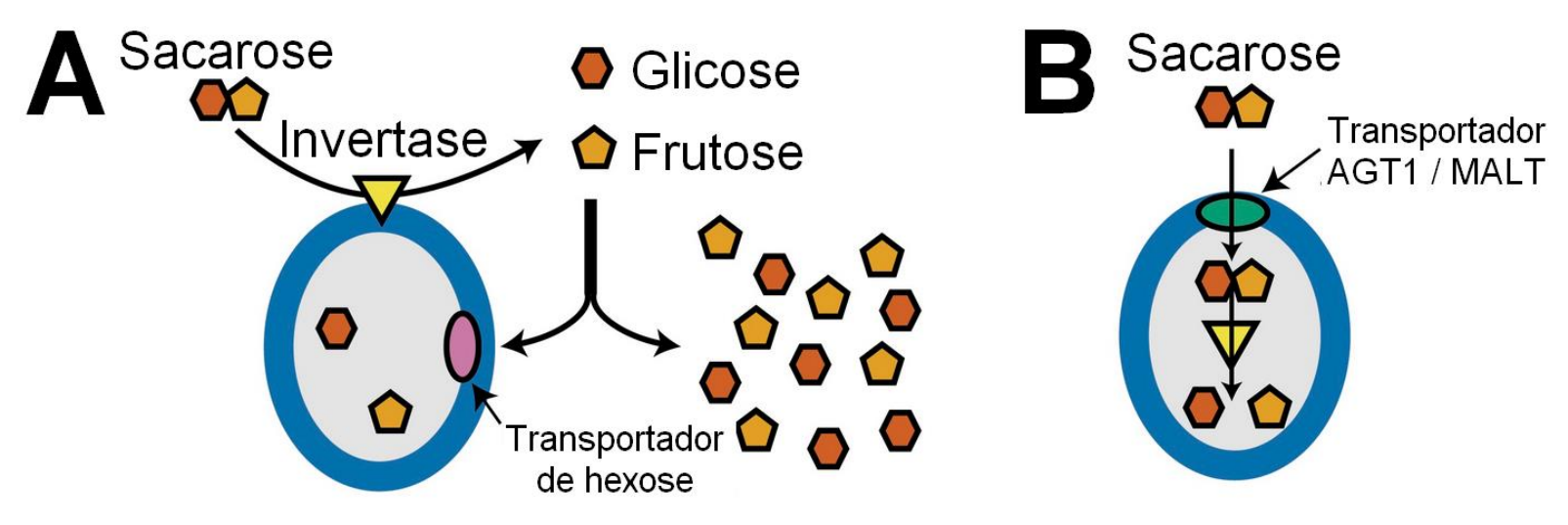

Figura 3. Metabolismo de sacarose em Saccharomyces cerevisiae (Modificada de Koschwanez et al.). $\mathrm{Em} \mathrm{A}$, a sacarose é hidrolisada pela invertase extracelular em glicose e frutose, que são absorvidas por meio de transportadores de hexose (HXT). Em B, a sacarose é absorvida por transportador AGT1 ou MALT e então hidrolisada pela invertase intracelular.

Durante o desenho experimental de pesquisa em produção heteróloga é vantajoso levar em consideração estratégias para otimizar a eficiência energética do biocatalisador, reduzindo níveis de sobrecarga metabólica pela produção das moléculas exógenas. De Kok et al. descreveram modificações no metabolismo de $S$. cerevisiae para aumentar o rendimento de ATP por molécula de maltose, estratégia que pode ser extrapolada para sacarose (Figura 4). Para tal, genes de enzimas invertase nativos da levedura são silenciados e essa é então transformada com um gene exógeno de sacarose fosforilase, poupando-se uma molécula de ATP para cada dissacarídeo metabolizado pelas células. Isso se deve ao fato de que, enquanto a invertase hidrolisa sacarose em glicose e frutose, que são subsequentemente fosforiladas na glicólise utilizando-se um ATP, a sacarose fosforilase catalisa a quebra da sacarose em frutose e glicose-1-fosfato utilizando um fosfato inorgânico. Ao substituir a primeira pela segunda, deixa-se de gastar uma molécula de ATP para fosforilar cada molécula de glicose, diminuindo o gasto de ATP por molécula de sacarose. 


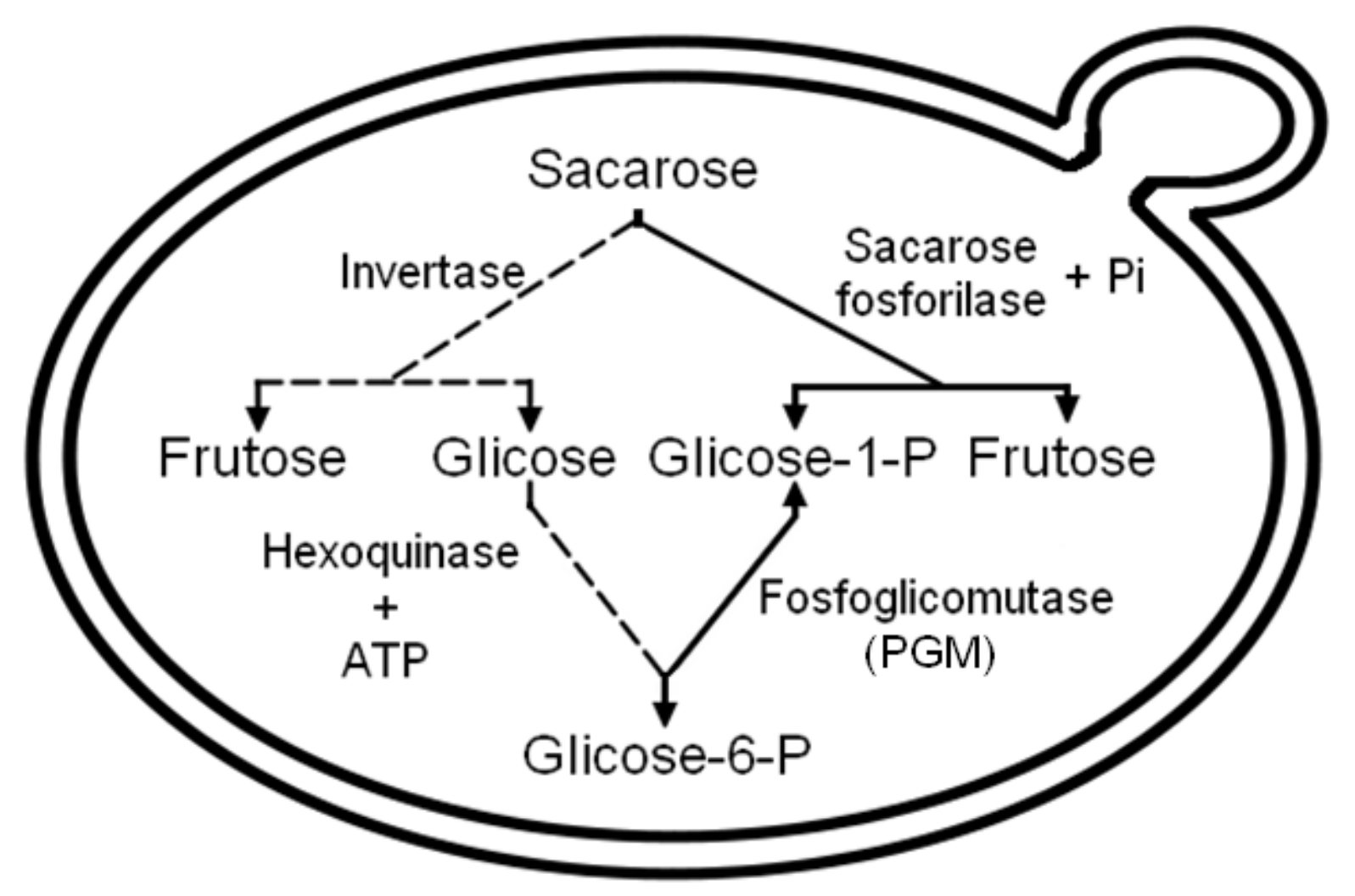

Figura 4. Estratégia para aumentar rendimento de ATP por molécula de sacarose. Linha descontínua: via desabilitada pelo silenciamento do gene para invertase. Linha contínua: via habilitada pela inserção do gene para sacarose fosforilase. 


\section{JUSTIFICATIVA}

A substituição de surfactantes químicos originados da indústria petrolífera pelos biossurfactantes é vantajosa, pois auxilia na redução da dependência por combustíveis fósseis. Ainda, por serem biodegradáveis e utilizarem substratos renováveis em sua produção, os biossurfactantes contribuem na redução de impactos ao meio ambiente. O ramnolipídeo é apontado como o mais promissor desses, mas até o presente momento não há nenhum processo em escala industrial para produção dessa molécula cujos custos consigam competir com a indústria de surfactantes sintéticos. A fim de minimizar o custo de produção, o presente estudo propôs a utilização de sacarose, substrato de baixo custo altamente disponível no Brasil devido ao tamanho e força da indústria sucroalcooleira, como substrato na produção de ramnolipídeo. Ainda com o mesmo fim, o presente projeto utilizou estratégias de engenharia metabólica para burlar a patogenicidade e ambiente regulatório do microrganismo produtor original, transferindo a via metabólica de síntese de ramnolipídeo para levedura. A S. cerevisiae é uma excelente candidata à produção heteróloga de ramnolipídeos devido a processos fermentativos industriais bem estabelecidos e grande disponibilidade de ferramentas genéticas disponíveis para sua manipulação. 


\section{OBJETIVOS}

\subsection{OBJETIVO GERAL}

O presente projeto tem como objetivo construir cepas recombinantes de $S$. cerevisiae para a produção de mono-ramnolipídeos a partir de sacarose.

\subsection{OBJETIVOS ESPECÍFICOS}

- Construção de cepa recombinante de $S$. cerevisiae com metabolismo direcionado para produção de dTDP-L-ramnose contendo interrupção do gene Suc2 e expressão dos genes de sacarose fosforilase, rmlA, rmlB, rmlC e rmlD;

- Construção de cepa recombinante de $S$. cerevisiae com metabolismo direcionado para produção de mono-ramnolipídeo contendo interrupção do gene Suc2 e expressão dos genes de sacarose fosforilase, rmlA, rmlB, rmlC, rmID, rhlA e rhlB;

- Desenvolvimento de métodos de detecção de dTDP-L-ramnose e monoramnolipídeos;

- Obtenção de pelo menos uma cepa recombinante de $S$. cerevisiae capaz de produzir mono-ramnolipídeos a partir de sacarose como prova de conceito. 


\section{MÉTODOS}

\subsection{GENES E PLASMÍDEOS}

Sete genes foram otimizados para expressão em levedura: Gft (sacarose fosforilase) de Pelomonas saccharophila e RmIA, RmIB, RmIC, RmID, RhIA e RhIB de $P$. aeruginosa. Foram sintetizados por empresa especializada e entregues em plasmídeos pBSK (Short et al., 1988). Foram então transformados em bactéria para estoque e amplificação do material genético e os vetores recuperados por kit comercial de extração de DNA plasmidial. Os genes foram transferidos para plasmídeos da coleção de Mumberg (Mumberg et al., 1995) por meio de estratégia clássica de clonagem utilizando enzimas de restrição para construção dos cassetes de expressão de levedura. Alguns cassetes foram então amplificados por meio de reação em cadeia da polimerase (PCR) com iniciadores desenhados para inserir sítios de restrição específicos flanqueando-os. Foram então digeridos e clonados em três plasmídeos finais: um contendo os genes Gft, RmIA e RmIC, outro contendo RmIB e RmID e um terceiro contendo RhIA e RhIB. A Tabela 3 mostra tamanhos dos genes, cassetes de expressão e plasmídeos utilizados nesse estudo.

\subsection{ESTRATÉGIA DE CLONAGEM}

O plasmídeo p425GPD recebeu o gene Gft entre seus promotor GPD e terminador CYC1. Nele foi inserido o cassete de expressão de RmIA contendo promotor TEF e terminador CYC1 e o cassete de expressão de RmIC contendo promotor CYC1 e terminador CYC1, resultando no plasmídeo pGAC. O plasmídeo p426GPD recebeu o gene RmIB entre seus promotor GPD e terminador CYC1. Nele foi inserido o cassete de expressão de RmID contendo promotor TEF e terminador CYC1, resultando no plasmídeo pBD. O plasmídeo p424TEF recebeu o gene RhIA entre seus promotor TEF e terminador CYC1. Nele foi inserido o cassete de expressão de RhIB contendo promotor ADH e terminador CYC1. Essa estratégia pode ser visualizada na Figura 5 e os iniciadores utilizados nesse estudo para amplificação de 
cassetes de expressão e confirmação de construção de plasmídeos por PCR podem ser visualizados na Tabela 4.

Tabela 3. Nome e tamanho dos genes, cassetes de expressão e plasmídeos utilizados nesse estudo.

\begin{tabular}{|c|c|c|c|c|c|}
\hline Nome & $\begin{array}{c}\text { Tamanho } \\
\text { (pb) }\end{array}$ & Referência & Nome & $\begin{array}{c}\text { Tamanho } \\
\text { (pb) }\end{array}$ & Referência \\
\hline Gft & 1505 & $\begin{array}{c}\text { Otimizado } \\
\text { nesse estudo }\end{array}$ & $\begin{array}{c}\text { Cassete GPDp- } \\
\text { Gft-CYC1t }\end{array}$ & 2503 & Esse estudo \\
\hline $\mathrm{RmIA}$ & 893 & $\begin{array}{c}\text { Otimizado } \\
\text { nesse estudo }\end{array}$ & $\begin{array}{c}\text { Cassete TEFp- } \\
\text { rmIA-CYC1t }\end{array}$ & 1604 & Esse estudo \\
\hline RmlB & 1070 & $\begin{array}{c}\text { Otimizado } \\
\text { nesse estudo }\end{array}$ & $\begin{array}{c}\text { Cassete GPDp- } \\
\text { rmIB-CYC1t }\end{array}$ & 2068 & Esse estudo \\
\hline $\mathrm{RmIC}$ & 557 & $\begin{array}{c}\text { Otimizado } \\
\text { nesse estudo }\end{array}$ & $\begin{array}{c}\text { Cassete CYC1p- } \\
\text { rmIC-CYC1t }\end{array}$ & 1152 & Esse estudo \\
\hline RmID & 921 & $\begin{array}{c}\text { Otimizado } \\
\text { nesse estudo }\end{array}$ & $\begin{array}{c}\text { Cassete TEFp- } \\
\text { rmID-CYC1t }\end{array}$ & 1620 & Esse estudo \\
\hline RhIA & 899 & $\begin{array}{c}\text { Otimizado } \\
\text { nesse estudo }\end{array}$ & $\begin{array}{c}\text { Cassete TEFp- } \\
\text { rhIA-CYC1t }\end{array}$ & 1607 & Esse estudo \\
\hline RhIB & 1292 & $\begin{array}{c}\text { Otimizado } \\
\text { nesse estudo }\end{array}$ & $\begin{array}{c}\text { Cassete ADHp- } \\
\text { rhIB-CYC1t }\end{array}$ & 3037 & Esse estudo \\
\hline pBSK & 2958 & $\begin{array}{c}\text { Short et al., } \\
1988\end{array}$ & P416TEF & 5526 & $\begin{array}{c}\text { Mumberg et } \\
\text { al., } 1995\end{array}$ \\
\hline p424ADH & 7309 & $\begin{array}{c}\text { Mumberg et } \\
\text { al., } 1995\end{array}$ & P426CYC1 & 5411 & $\begin{array}{c}\text { Mumberg et } \\
\text { al., } 1995\end{array}$ \\
\hline p424TEF & 6246 & $\begin{array}{c}\text { Mumberg et } \\
\text { al., } 1995\end{array}$ & P426GPD & 6637 & $\begin{array}{c}\text { Mumberg et } \\
\text { al., } 1995\end{array}$ \\
\hline p425GPD & 7760 & $\begin{array}{c}\text { Mumberg et } \\
\text { al., } 1995\end{array}$ & P426TEF & 6352 & $\begin{array}{c}\text { Mumberg et } \\
\text { al., } 1995\end{array}$ \\
\hline
\end{tabular}



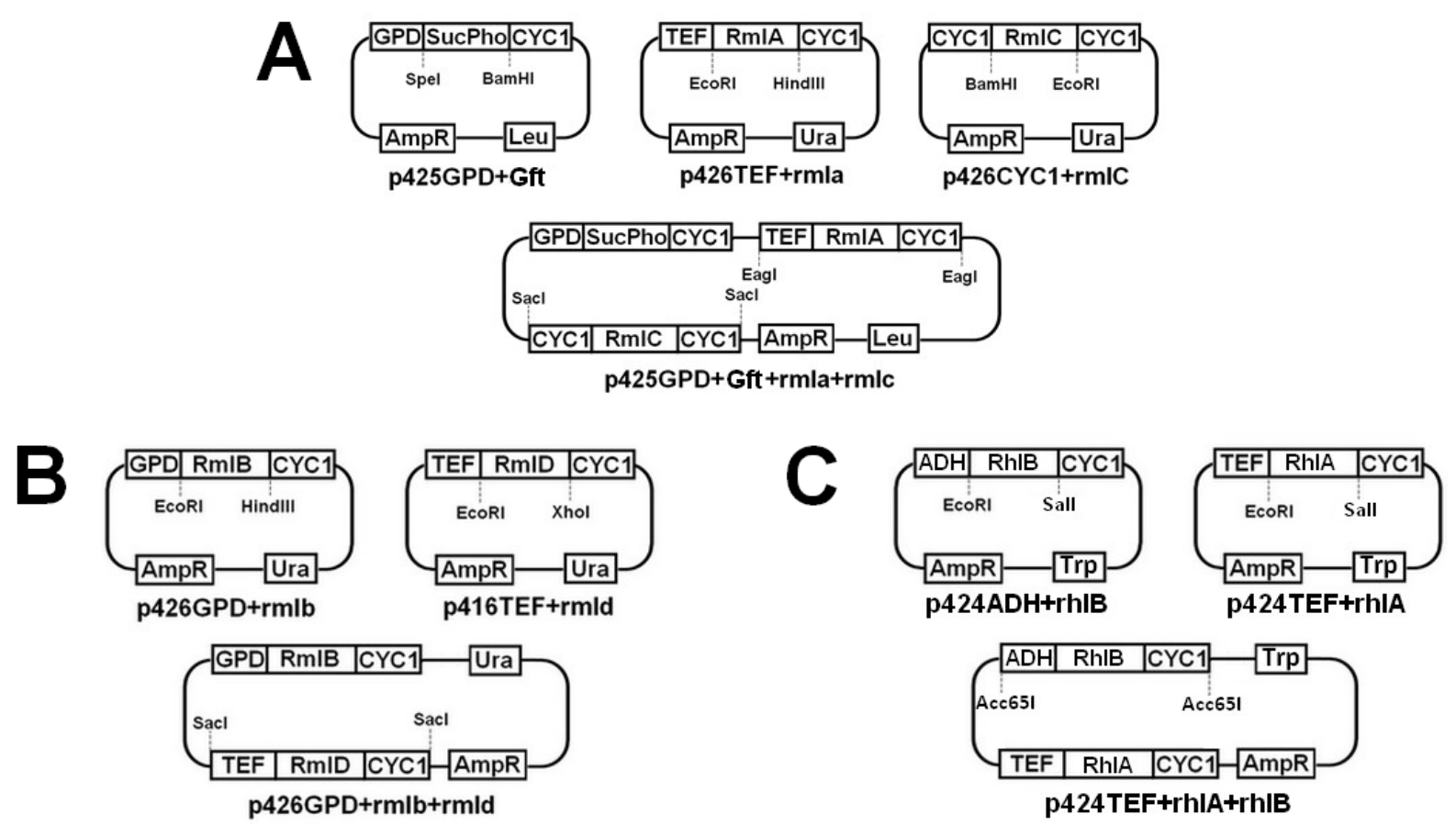

Figura 5. Estratégia de clonagem dos plasmídeos pGAC - p425GPD+Gft+RmlA+RmlC (A), pBD p426GPD+RmIB+RmID (B) e pAB - p424TEF+RhIA+RhIB (C).

\subsection{INTERRUPÇÃO DO GENE SUC2}

A interrupção do gene SUC2 nas cepas de Saccharomyces cerevisiae foi feita a partir da transformação da levedura com um cassete de interrupção KanMX contendo a marca de seleção ao antibiótico geneticina G418, como já descrito anteriormente (Güldener et al., 1996). Dois iniciadores de interrupção foram desenhados de modo a adicionar regiões homólogas ao gene SUC2 nas extremidades do cassete de KanMX. O cassete foi amplificado por PCR com os iniciadores supracitados tendo o plasmídeo pUG6 (Güldener et al, 1996) como molde e transformado em levedura por protocolo de transformação previamente descrito (Hill et al., 1991). Cepas recombinantes foram selecionadas em placa de YPD suplementadas com geneticina $(0,02 \mathrm{~g} / \mathrm{ml}$ de peptona, $0,01 \mathrm{~g} / \mathrm{ml}$ de extrato de levedura, $0,02 \mathrm{~g} / \mathrm{ml}$ de ágar e $5 \mathrm{mg} / \mathrm{ml}$ de geneticina). Três iniciadores de verificação foram desenhados de modo a se alinharem em regiões a montante e a jusante dos sítios de recombinação onde o cassete de KanMX interrompeu o gene SUC2 e também no meio de KanMX. Verificação da interrupção de SUC2 nas cepas foi realizada por meio de PCR de colônia com os iniciadores supracitados. Informações sobre os iniciadores 
podem ser visualizadas na Tabela 5 e a estratégia de interrupção pode ser visualizada na Figura 6.

Tabela 4. Iniciadores usados na amplificação de cassetes de expressão e na confirmação de construção de plasmídeos desse estudo.

\begin{tabular}{clc}
\hline Nome & Sequência (Sítio de restrição, quando aplicável) & Tm (ํ) \\
\hline rmIAF_cassette & AATGCGGCCGCAAATAAAGCCTTCGAG (Eagl) & 65.2 \\
rmIAR_cassette & ATTGCGGCCGCAAATGTTTCTACTCCTT (Eagl) & 62.7 \\
rmICF_cassette & GTAGAGCTCGCTCATTTGGCGAGCGTTG (Sacl) & 65.8 \\
rmICR_cassette & GTAGAGCTCGGGCGAATTGGGTACCGGC (Sacl) & 67.3 \\
rmIDF_cassette & GTAGAGCTCGTACCGGCCGCAAATTAAA (Sacl) & 62.4 \\
rmIDR_cassette & GTAGAGCTCCATAGCTTCAAAATGTTTCT (Sacl) & 59.7 \\
rhIBF_cassette & ATAGGTACCGCGCAATTAACCCTCAC (Acc65I) & 52.9 \\
rhIBR_cassette & GGTACCCAATTCGCCTATA (Acc65I) & 52.7 \\
GftF_confirm & TCACATACGTAGATAGGTTGG & 51.9 \\
GftR_confirm & GAGAATGCAAAGGCTCTATC & 52.2 \\
rmIAF_confirm & GAGGAAAGGTATCATATTGGC & 51.9 \\
rmIAR_confirm & AGTAGACAGTTTCAGTCAACA & 51.5 \\
rmIBF_confirm & GACTATATTGGTTACAGGTTCAG & 51.3 \\
rmIBR_confirm & CATGCATACTGTTTACCTACC & 51.5 \\
rmICF_confirm & AGCTACTAGATTGGCTATCC & 51.9 \\
rmICR_confirm & TTATGGGAAACAATCAGCATC & 51.7 \\
rmIDF_confirm & GAATCTTATTATTGGGAGCCAA & 51.4 \\
rmIDR_confirm & TCACAATGGTCCCTGTT & 51.4 \\
rhIAF_confirm & ATGAGAAGGGAAAGTTTATTGG & 51.2 \\
rhIAR_confirm & GGCATAGCCGATAGC & 51.1 \\
rhIBF_confirm & GCACGCCATCTTGATAG & 51.8 \\
rhIBR_confirm & TTAAGAAGCAGCCTTCAAC & 51.4 \\
\hline
\end{tabular}


Tabela 5. Iniciadores usados na amplificação do cassete de interrupção e na verificação da interrupção.

\begin{tabular}{ccl}
\hline & Nome & \multicolumn{1}{c}{ Sequência } \\
\hline \multirow{2}{*}{$\begin{array}{c}\text { Iniciadores de } \\
\text { interrupção }\end{array}$} & SUC2-fwd & TCTCTCAGAGAAACAAGCAAAACAAAAAGCTTTTCTT \\
& SUC2-rev & GCTAAAGCCCTTTAGAATGGCTTTTGAAAAAAATAAA \\
& AAGCATAGGCCACTAGTGGATCTG \\
& CH-fwd & GTTTAGGAAATTATCCGGGGGC \\
Iniciadores de & CH-rev & GCTTGGTATCCATTTCCCTCAC \\
verificação & MidK-rev & CGCGATCGCTGTTAAAAGGAC \\
\hline
\end{tabular}

\section{Cromossomo IX}

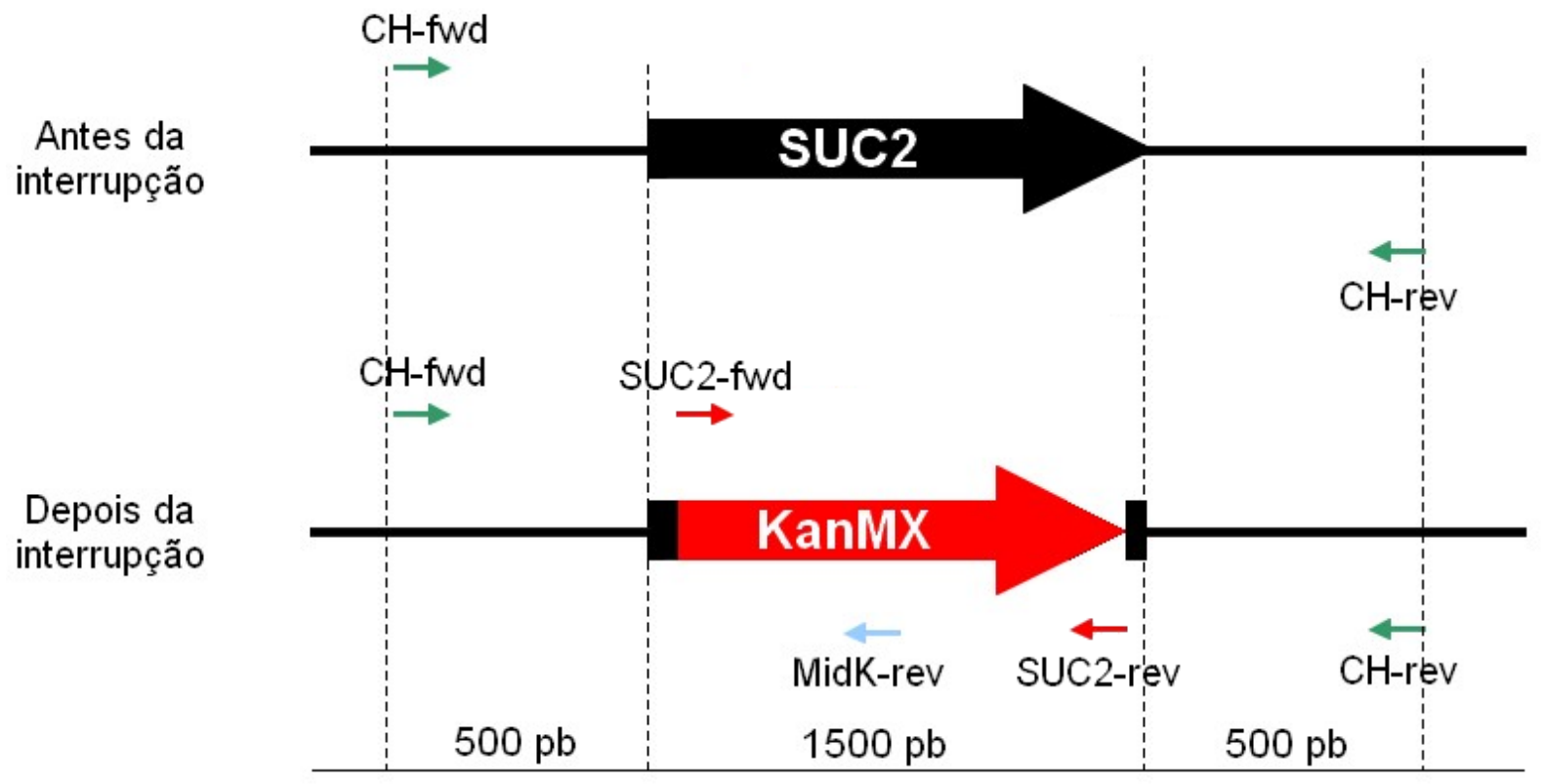

Figura 6. Estratégia de interrupção do gene SUC2. As setas pequenas indicam os iniciadores utilizados no estudo. Em vermelho, iniciadores de interrupção. Em verde, iniciadores de verificação que anelam 500 pares de base a jusante e a montante do locus de SUC2 no cromossomo IX da levedura. Em azul, iniciador de verificação que anela dentro do cassete KanMX, a 1300 pares de base de distância do sítio de anelamento de $\mathrm{CH}$-fwd. 


\subsection{CEPAS}

E. coli DH5- $\alpha$ foi utilizada para propagação e manipulação de DNA recombinante durante construção dos plasmídeos. Transformações foram realizadas seguindo protocolo de eletroporação descrito em manual do eletroporador da empresa BioRad (Hercules, EUA). Transformantes foram crescidos a $37^{\circ} \mathrm{C}$ em meio LB ( $5 \mathrm{~g} / \mathrm{L}$ extrato de levedura, $10 \mathrm{~g} / \mathrm{L} \mathrm{NaCl}$ e $10 \mathrm{~g} / \mathrm{L}$ triptona) contendo ampicilina a $0,1 \mathrm{~g} / \mathrm{L}$. As cepas bacterianas utilizadas e produzidas nesse estudo podem ser visualizadas na Tabela 6.

Tabela 6. Nome, genótipo relevante e cepa parental das cepas bacterianas utilizadas e produzidas nesse estudo.

\begin{tabular}{clc}
\hline Nome & \multicolumn{1}{c}{ Genótipo relevante } & Cepa parental \\
\hline DH5- $\alpha$ & & - \\
Ec-G & pBSK Gft & DH5- $\alpha$ \\
Ec-A & pBSK RmIA & DH5- $\alpha$ \\
Ec-B & pBSK RmIB & DH5- $\alpha$ \\
Ec-C & pBSK RmIC & DH5- $\alpha$ \\
Ec-D & pBSK RmID & DH5- $\alpha$ \\
Ec-HA & pBSK RhIA & DH5- $\alpha$ \\
Ec-HB & pBSK RhIB & DH5- $\alpha$ \\
Ec-CasG & p425GPD Gft & DH5- $\alpha$ \\
Ec-CasA & p426TEF RmIA & DH5- $\alpha$ \\
Ec-CasB & p426GPD RmIB & DH5- $\alpha$ \\
Ec-CasC & p426CYC1 RmIC & DH5- $\alpha$ \\
Ec-CasD & p416TEF RmID & DH5- $\alpha$ \\
Ec-CasHA & p424TEF RhIA & DH5- $\alpha$ \\
Ec-CasHB & p424ADH RhIB & DH5- $\alpha$ \\
Ec-CasGA & p425GPD Gft RmIA & DH5- $\alpha$ \\
Ec-CasGAC & p425GPD Gft RmIA RmIC & DH5- $\alpha$ \\
Ec-CasBD & p426GPD RmIB RmID & DH5- $\alpha$ \\
Ec-CasHAB & p424TEF RhIA RhIB & DH5- $\alpha$ \\
\hline
\end{tabular}


Duas cepas de $S$. cerevisiae foram utilizadas: CEN.PK 102-3A para construção de cepa produtora de dTDP-L-ramnose (RHP) e sua cepa referência (RHR); CEN.PK 113-6B para construção de cepa produtora de mono-ramnolipídio (RLP) e sua cepa referência (RLR) (Tabela 7). Transformações foram realizadas seguindo protocolo descrito por Hill et al. (1991). Ambas as cepas tiveram o gene SUC2 interrompido utilizando cassete de interrupção KanMX proveniente do plasmídeo pUG6 (Güldener et al, 1996) que confere resistência a G418 (geneticina). Transformantes foram selecionados a $30^{\circ} \mathrm{C}$ em meio YPD (10 g/L extrato de levedura, $20 \mathrm{~g} / \mathrm{L}$ peptona e 20 $\mathrm{g} / \mathrm{L}$ D-glicose) contendo G418 a 0,2 g/L. As cepas resultantes da interrupção foram então transformadas com os plasmídeos necessários para a produção de dTDP-Lramnose ( $p G A C$ e pBD) ou mono-ramnolipídeo ( $p G A C, p B D$ e pAB), assim como com os plasmídeos vazios (p425GPD, p426GPD, p424TEF) para criação de cepas prototróficas de referência. Transformantes foram selecionados a $30^{\circ} \mathrm{C}$ em meio YNB contendo glicose $20 \mathrm{~g} / \mathrm{L}$ e complementado com aminoácidos/nucleotídeos necessários para seleção de recombinantes. Recombinantes foram confirmados por meio de PCR de colônia utilizando iniciadores específicos para cada gene (Tabela 4). As cepas de levedura utilizadas e produzidas nesse estudo podem ser visualizadas na Tabela 7. Essas cepas encontram-se depositadas na coleção do grupo de Engenharia de Biocatalisadores do laboratório de Biologia Molecular da Universidade de Brasília. 
Tabela 7. Nome, genótipo relevante e cepa parental das cepas de levedura utilizadas e produzidas nesse estudo.

\begin{tabular}{|c|c|c|}
\hline Nome & Genótipo relevante & Cepa parental \\
\hline CEN.PK 102-3A & MATa SUC2 MAL2-8c LEU2 URA3-52 & - \\
\hline $\mathrm{RH} 1$ & $\begin{array}{l}\text { MATa SUC2 MAL2-8c LEU2 URA3-52 } \\
\text { suc2::KanMX }\end{array}$ & CEN.PK 102-3A \\
\hline $\mathrm{RH} 2$ & $\begin{array}{l}\text { MATa SUC2 MAL2-8c LEU2 URA3-52 } \\
\text { suc2::KanMX p425GPD }\end{array}$ & $\mathrm{RH} 1$ \\
\hline $\mathrm{RH} 3(\mathrm{RHR})$ & $\begin{array}{l}\text { MATa SUC2 MAL2-8c LEU2 URA3-52 } \\
\text { suc2::KanMX p425GPD p426GPD }\end{array}$ & $\mathrm{RH} 2$ \\
\hline $\mathrm{RH} 4$ & $\begin{array}{l}\text { MATa SUC2 MAL2-8c LEU2 URA3-52 } \\
\text { suc2::KanMX p425GPD Gft rmIA rmIC } \\
\text { MATa SUC2 MAL2-8c LEU2 URA3-52 }\end{array}$ & $\mathrm{RH} 1$ \\
\hline $\mathrm{RH} 5$ (RHP) & $\begin{array}{l}\text { suc2::KanMX p425GPD p426GPD GFT RMLA } \\
\text { RMLC RMLB RMLD }\end{array}$ & $\mathrm{RH} 4$ \\
\hline CEN.PK 113-6B & MATa SUC2 MAL2-8c LEU2 URA3-52 TRP1 & \\
\hline RL1 & $\begin{array}{l}\text { MATa SUC2 MAL2-8c LEU2 URA3-52 TRP1 } \\
\text { suc::KanMX }\end{array}$ & CEN.PK 113-6B \\
\hline RL2 & $\begin{array}{l}\text { MATa SUC2 MAL2-8c LEU2 URA3-52 TRP1 } \\
\text { suc::KanMX p426GPD }\end{array}$ & RL1 \\
\hline RL3 & $\begin{array}{l}\text { MATa SUC2 MAL2-8c LEU2 URA3-52 TRP1 } \\
\text { suc::KanMX p426GPD p425GPD }\end{array}$ & RL2 \\
\hline RL4 (RLR) & $\begin{array}{l}\text { MATa SUC2 MAL2-8c LEU2 URA3-52 TRP1 } \\
\text { suc::KanMX p426GPD p425GPD p424TEF }\end{array}$ & RL3 \\
\hline RL5 & $\begin{array}{l}\text { MATa SUC2 MAL2-8c LEU2 URA3-52 TRP1 } \\
\text { suc::KanMX p426GPD rmIB rmID }\end{array}$ & RL1 \\
\hline RL6 & $\begin{array}{l}\text { MATa SUC2 MAL2-8c LEU2 URA3-52 TRP1 } \\
\text { suc::KanMX p426GPD p425GPD rmIB rmID Gft } \\
\text { rmIA rmIC }\end{array}$ & RL5 \\
\hline RL7 (RLP) & $\begin{array}{l}\text { MATa SUC2 MAL2-8c LEU2 URA3-52 TRP1 } \\
\text { suc::KanMX p426GPD p425GPD p424TEF rmIB } \\
\text { rmID Gft rmIA rmIC rhlA rhIB }\end{array}$ & RL6 \\
\hline
\end{tabular}




\subsection{CURVAS DE CRESCIMENTO}

As curvas de crescimento das cepas de levedura foram realizadas a $30^{\circ} \mathrm{C} \mathrm{e}$ 200 rpm em meio YNB (Base de Nitrogênio para Levedura) sem aminoácidos (aa's) contendo fonte de nitrogênio adicionado de glicose ou sacarose a 2\% e CSM (Mistura Completa de Suplementos) deficiente especificamente nas necessidades auxotróficas das cepas que estão sendo supridas pelo(s) plasmídeo(s) que carregam, quando carregam, podendo ser leucina, uracila, triptofano ou combinação desses. Quando aplicável, o meio era adicionado de solução de LiCl (Cloreto de lítio) para $15 \mathrm{mM}$. Os experimentos froam realizados em triplicatas de $25 \mathrm{~mL}$ do meio supracitado. Amostragens foram realizadas de duas em duas horas e a OD (densidade ótica) a $620 \mathrm{~nm}$ medida para cada amostra. Os dados de OD e tempo de fermentação foram então digitalizados em tabela. Calculou-se o logaritmo natural para os valores de OD, que foram então transformados em gráfico de linha, um para cada triplicata. Escolheuse arbitrariamente o conjunto de dados que representava a região com crescimento linear na tabela, representando a fase de crescimento exponencial das cepas. Calculando-se o coeficiente angular das retas, ontém-se o valor da taxa de crescimento específico máxima ( $\mu_{\text {máx }}$ para cada triplicata. Calculou-se então a média

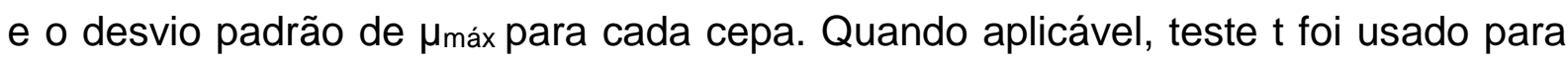

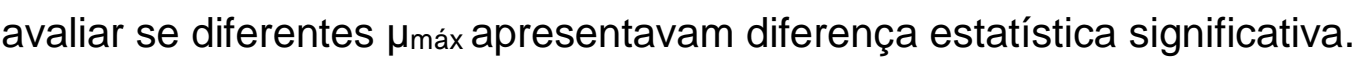

\subsection{ENSAIO ENZIMÁTICO}

As extrações de proteínas totais foram realizadas com o Reagente de Extração de Proteínas para Leveduras Y-PER ${ }^{\mathrm{TM}}$ da empresa Thermo Scientific ${ }^{\circledR}$ como especificado pelo manual do fabricante. As extrações eram feitas e imediatamente levadas para análise de atividade enzimática.

O ensaio colorimétrico acoplado para detecção da atividade enzimática de RmIA foi realizado como descrito por Sha et al. (2012). A reação enzimática continha $50 \mathrm{mM}$ Tris ( $\mathrm{pH} 7,5$ ), $1 \mathrm{mM}$ ditiotreitol, $10 \%$ de glicerol, $5 \mathrm{mM} \mathrm{MgCl} 2,0,2 \mathrm{mM}$ dTTP, $1 \mathrm{mM}$ D-Gli-1-P e 0,04 unidades de pirofosfatase. Uma unidade de pirofosfatase foi definida como a quantidade de enzima necessária para causar o aparecimento de 1,0 $\mu \mathrm{mol}$ de 
Pi por minuto a pH 7,2 e $25^{\circ} \mathrm{C}$. A reação foi iniciada pela adição do extrato celular. Depois de incubação da reação a $37^{\circ} \mathrm{C}$ por 5 minutos, a reação foi terminada com adição de uma solução contendo $0,03 \%(\mathrm{p} / \mathrm{v})$ do reagente malachite green, $0,2 \%(\mathrm{p} / \mathrm{v})$ de molibidato de amônio e 0,05\% (v/v) Triton X-100 em 0,7 N HCl a $37^{\circ} \mathrm{C}$ por mais 5 minutos. A absorbância das amostras foi medida a 630nm (OD630nm). Os ensaios foram feito em triplicatas biológicas.

\subsection{ANÁLISE DE DTDP-L-RAMNOSE}

\subsubsection{Cromatografia de Troca-Aniônica de Alta-Performance}

Método previamente descrito (Räbinä et al., 2001) para preparação e extração de amostras de açúcares-nucleotídeos foi utilizado nesse estudo com algumas modificações. Rompimento celular. Para a preparação de lisados de células de levedura, as cepas RHR e RHP (Tabela 7) foram crescidas em meio YNB com sacarose $2 \%$ e CSM-Leu-Ura (Mistura Completa de Suplementos sem leucina e uracila) por 48 horas, coletadas por centrifugação a $5000 \mathrm{~g}$ por 5 minutos e ressuspendidas em Tampão de Lise composto por MOPS-NaOH (pH 7,5) 50mM, Triton X-100 1\% e glicerol 10\%. Então, microesferas de vidro foram adicionadas às amostras na proporção em volume 1:3 e agitadas intensamente em equipamento FastPrep ${ }^{\circledR}$ (MP Biomedicals, Santa Ana, EUA) com 6 ciclos de 30 segundos em velocidade 6 e 5 minutos descansando em gelo. Após a lise mecânica, os lisados celulares foram centrifugados por 10 minutos a $20000 \mathrm{~g}$ e o sobrenadante coletado e armazenado a $-20^{\circ} \mathrm{C}$ para análises subsequentes. Extração de dTDP-Rha. A Extração em Fase Sólida (SPE) de dTDP-Rha foi realizada com colunas de carbono grafitizado poroso ENVI-Carb ${ }^{\text {TM }}$ Supelclean ${ }^{\text {TM }}$ (Sigma-Aldrich, Darmstadt, Alemanha) e é dividida em quatro etapas: Condicionamento da coluna: aplicar $3 \mathrm{~mL}$ de solução de acetonitrila $80 \%$ (v/v) e ácido trifluoroacético $0,1 \%$ (v/v) seguidos de $2 \mathrm{~mL}$ de água; Adição de amostra: diluir amostras com bicarbonato de amônia $10 \mathrm{mM}$ para volume final de $1 \mathrm{~mL}$ e aplicar na coluna; Procedimento de Lavagem: aplicar $2 \mathrm{~mL}$ de água seguidos de $2 \mathrm{~mL}$ de acetonitrila $25 \%$ (v/v) e $2 \mathrm{~mL}$ de tampão TEAA (acetato de trietilamônia) 50mM (pH 7,0); Eluição: aplicar $1 \mathrm{~mL}$ de tampão TEAA 50mM $(\mathrm{pH} 7,0)$ 
contendo acetonitrila $25 \%(\mathrm{v} / \mathrm{v})$. As etapas foram realizadas de modo que a coluna de carbono nunca secasse, mantendo um fluxo contínuo das consecutivas soluções. As amostras foram coletadas, concentradas a vácuo e armazenadas a $-20^{\circ} \mathrm{C}$ até análise.

Método previamente descrito (Köplin et al., 1997) para análise de açúcaresnucleotídeos por Cromatografia de Troca-Aniônica de Alta-Performance (HPAEC) foi utilizado nesse estudo com algumas modificações. Coluna CarboPac ${ }^{\mathrm{TM}}$ PA1 Dionex ${ }^{\mathrm{TM}}$ (Thermo Scientific, Waltham, EUA) foi utilizada com os seguintes parâmetros de equipamento: Fase móvel: gradiente de acetato de sódio $200 \mathrm{mM}-500 \mathrm{mM}(\mathrm{pH} \mathrm{7,0)}$; Temperatura: $26^{\circ} \mathrm{C}$; Taxa de fluxo: $0,6 \mathrm{~mL} / \mathrm{min}$; Tempo de corrida: 50 minutos; Detecção: PDA a 262nm.

\subsubsection{Espectrometria de Massa em Tandem}

Os experimentos a seguir foram realizados em parceria com a doutoranda Christiane Campos, supervisionada pela pesquisadora Dra. Patrícia Abdelnur, do Laboratório de Química de Biomassa e Biocombustíveis do Centro Nacional de Pesquisa de Agroenergia (CNPAE) - EMBRAPA Agroenergia. Método previamente descrito (González e Franc, 1997) para extração de metabólitos geral foi utilizado nesse estudo com algumas modificações. Rompimento celular. Para a preparação de lisados de células de levedura, as cepas RHR e RHP (Tabela 7) foram crescidas em meio YNB com sacarose 2\% e CSM-Leu-Ura (Mistura Completa de Suplementos sem leucina e uracila) por 48 horas. $1 \mathrm{~mL}$ foi amostrado de cada cultura e adicionadas em proporção $1: 1(\mathrm{v} / \mathrm{v})$ com solução tampão contendo etanol $75 \%(\mathrm{v} / \mathrm{v})$ e acetato de

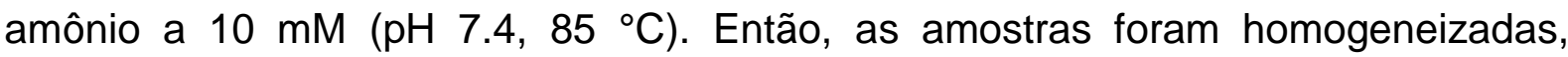
incubadas com agitação vigorosa a 800 rpm por 3 minutos a $85^{\circ} \mathrm{C}$ e resfriadas a -40 ${ }^{\circ} \mathrm{C}$ em banho termostático. Após o resfriamento, foi realizada uma centrifugação a 5000 rpm e $-9{ }^{\circ} \mathrm{C}$ por 3 minutos para separar os restos celulares. Os sobrenadantes foram transferidos para um novo tubo e concentrados a vácuo. Todas as amostras foram estocadas a - $80{ }^{\circ} \mathrm{C}$. MS/MS. As análises foram feitas usando um sistema ACQUITY UPLC (Waters, Milford, EUA) acoplado a um espectrômetro de massa triplo quadrupolo (Xevo TQD - Waters, Milford, EUA) equipado com uma fonte de ionização por eletrospray. Espectrometria de massa por infusão direta (do ingles Direct Infusion Mass Spectrometry - DIMS) foi usada para aperfeiçoar as condições de análise por 
Monitoramento de Reações Múltiplas (MRM). Uma solução padrão de dTDP-Lramnose $(20 \mu \mathrm{g} / \mathrm{mL})$ foi aplicada e a voltagem do cone mais intensa foi $40 \mathrm{~V}$. Para MS/MS, a energia de colisão foi de 20V. O MS foi operado em modo de ionização negativo ESI(-)-MS. Os parâmetros instrumentais usados no espectrômetro de massa foram: voltagem capilar $3500 \mathrm{~V}$, temperatura de solvatação de $450^{\circ} \mathrm{C}$, temperatura da fonte: $130^{\circ} \mathrm{C}$, fluxo de gás: $20 \mathrm{~L} / \mathrm{h}$ e fluxo de gás de solvatação: $700 \mathrm{~L} / \mathrm{h}$. A separação cromatográfica foi feita com uma coluna HSS-T3 (C18) com dimensões $2.1 \times 150 \mathrm{~mm}$ x $1.8 \mu \mathrm{m}$ (Waters). A fase móvel era composta por uma solução aquosa contendo $0,1 \%$ de acido fórmico em modo de eluição isocrática com fluxo de $0.4 \mathrm{~mL} / \mathrm{min}$. A temperatura da coluna foi mantida a $45^{\circ} \mathrm{C}$. Cada análise durou 5 minutos.

\subsection{ANÁLISE DE MONO-RAMNOLIPÍDEOS}

\subsubsection{Ensaio de Orcinol}

Método previamente descrito (Christova et al., 2003) para extração e detecção de RLS foi utilizado nesse estudo com algumas modificações. Para a obtenção de sobrenadantes e lisados de células de levedura, as cepas RLR e RLP (Tabela 7) foram crescidas em meio YNB com sacarose 2\% e CSM-Leu-Ura-Trp (Mistura Completa de Suplementos sem leucina, uracila e triptofano) por 48 horas. Foram amostrados $2 \mathrm{~mL}$ de cada cultura que foram subsequentemente centrifugados a $3000 \mathrm{~g}$ por 3 minutos. O sobrenadante foi coletado e o sedimentado celular foi submetido a método de rompimento utilizando Y-PER ${ }^{\mathrm{TM}}$ (Thermo Scientific, Waltham, EUA). Amostras de sobrenadante e lisado celular foram então acidificadas com $\mathrm{HCL}$ até atingirem pH 2,0. Então, $333 \mu \mathrm{L}$ de amostra foi adicionado de $1 \mathrm{~mL}$ de dietil éter e agitada em homogeneizador de bancada por 5 minutos. A fração de éter foi coletada e a fração de água remanescente foi submetida novamente ao passo anterior. A fração de éter foi novamente coletada, unida com a anterior e as amostras foram então evaporadas em temperatura ambiente em tubos abertos em bancada. $O$ sedimento remanescente foi ressuspendido em $100 \mu \mathrm{L}$ de água bidestilada e adicionado de $900 \mu \mathrm{L}$ de orcinol (1,3-dihidroxi-5-metil benzeno) $0,19 \%$ em ácido sulfúrico $53 \%$. A solução resultante foi então aquecida por 30 minutos a $80^{\circ} \mathrm{C}$, resfriada em temperatura ambiente por 15 
minutos e submetida a leitura de densidade ótica a $421 \mathrm{~nm}$. Além das amostras das cepas de levedura, uma curva padrão utilizando dTDP-Rha foi criada com diferentes concentrações dessa submetidas à mesma metodologia acima. Ensaios foram realizados em triplicata.

\subsubsection{Microscopia Confocal}

Os experimentos a seguir foram realizados em parceria com a mestranda Lorena Andrade, supervisionada pelo prof. Dr. José Corrêa Raiumundo, do Laboratório de Microscopia Eletrônica do Instituto de Ciências Biológicas (IB) Universidade de Brasília (UnB). Para ensaio alternativo de detecção de mono-RLs, as cepas foram crescidas em meio YNB com sacarose 2\% e CSM-Leu-Ura-Trp (Mistura Completa de Suplementos sem leucina, uracila e triptofano) até atingirem fase estacionária de crescimento após 48 horas. Então, as cepas RLR e RLP foram submetidas a ensaio de fluorescência para detecção de acúmulo de lipídeos intracelulares descrito a seguir.

Amostras das cepas RLR e RLP ( $10^{6}$ células) foram coletadas por centrifugação a $5000 \mathrm{~g}$ por 5 minutos, lavadas três vezes em PBS (do inglês Phosphate Saline Buffer), pH 7,4 e ressuspendidas em $50 \mu \mathrm{L}$ de solução de liticase a 35 unidades $/ \mathrm{mL}$. Foram então mantidas por 9 minutos a $30^{\circ} \mathrm{C}$ para a degradação da parede celular das leveduras. Subsequentemente, as amostras foram lavadas três vezes em PBS e incubadas por 1 hora a temperatura ambiente em solução de

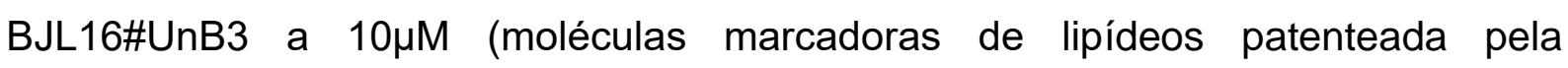
Universidade de Brasília). Novamente, as células foram lavadas 3 vezes em PBS e coletadas por centrifugação a $3000 \mathrm{~g}$ por 5 minutos para serem então ressuspendidas em PBS e adicionadas em placa de 24 poços contendo, no fundo desses, lamínulas circulares pré-tratadas com poli-L-lisina $0,1 \%$ para fixação das células. A placa foi submetida a centrifugação a $3000 \mathrm{~g}$ por 5 minutos, o sobrenadante retirado e as lamínulas colocadas sobre lâminas utilizando ProLong® Gold antifade mountant solution (Thermo-Fisher, Waltham, USA). As amostras foram analisadas por Microscopia Confocal de Varredura a Laser, Leica TCS SP5 (New Jersey, USA) sob emissão de laser a comprimento de onda $488 \mathrm{~nm}$. Todos os ensaios foram realizados em triplicata e repetidos três vezes. 
Para a análise de fluorescência celular, foram adquiridas vinte imagens aleatoriamente de diferentes campos para cada amostra. Os campos foram selecionados e analisados baseados em aspectos morfológicos das células através de imagem de campo claro. Não foram utilizados dados de fluorescência para seleção das imagens, a fim de evitar amostragem tendenciosa. Trezentas células foram analisadas em triplicata utilizando programa ImageJ (Maryland, USA) de modo a avaliar o número médio de células a apresentarem sinal de fluorescência. Ademais, foi determinado o número médio de pontos de fluorescência para cada célula com sinal positivo para sinal de fluorescência. Os pontos de fluorescência são equivalentes a corpos lipídicos presentes no citoplasma das células. Finalmente, foi determinado o desvio padrão para o grupo de dados de cada amostra.

Para a análise de intensidade de fluorescência das imagens foi utilizado histograma gerado por image lockup table (LUT). As imagens foram também utilizadas para criar uma imagem térmica baseada em valores de pixels das imagens no LUT. A imagem térmica foi projetada como mapeamento $3 \mathrm{D}$ sobre as imagens térmicas primárias das amostras, gerando uma representação em histograma 3D sobre os pontos de fluorescência celulares, os quais são gotículas lipídicas. A intensidade de fluorescência emitida está intimamente associada à quantidade de lipídios nas gotículas lipídicas. Todas as análises foram realizadas utilizando programa ImageJ (Maryland, USA). 


\section{RESULTADOS E DISCUSSÃO}

\subsection{CONSTRUÇÃO DAS CEPAS}

\subsubsection{Interrupção do gene SUC2}

Duas cepas laboratoriais haploides de levedura foram selecionadas para abrigarem os plasmídeos contendo os genes necessários para produção de dTDP-Lramnose e mono-ramnolipídeos: CEN.PK 102-3A e CEN.PK 113-6B, respectivamente. No entanto, antes de inserir os genes da via de síntese de dTDPRHA, ambas as cepas tiveram o gene SUC2 interrompido, por meio de recombinação homóloga, com cassete de expressão KanMX contendo gene que confere resistência a geneticina (G418). Dessa maneira, colônias que se mostraram resistentes à geneticina após transformação com KanMX possuem, teoricamente, o gene SUC2 interrompido. Após triagem em meio de cultura sólido contendo G418, colônias positivas foram submetidas a PCR de colônia utilizando os iniciadores de verificação apresentados na Tabela 5. Como esquematizado na Figura 6, o par de iniciadores $\mathrm{CH}$-fwd e $\mathrm{CH}$-rev gera fragmento de aproximadamente $2500 \mathrm{pb}$ em cepas com SUC2 interrompido ou não. Já o par de iniciadores $\mathrm{CH}$-fwd e MidK-ver gera fragmento de 1300 pb apenas em cepa que possui KanMX interrrompendo o gene SUC2. Como pode ser verificado na Figura 7, a amostra 1 (A1) de ambas as cepas mostraram padrão de bandas esperado para interrupção de SUC2, sendo então estocadas e usadas para posteriores transformações. 


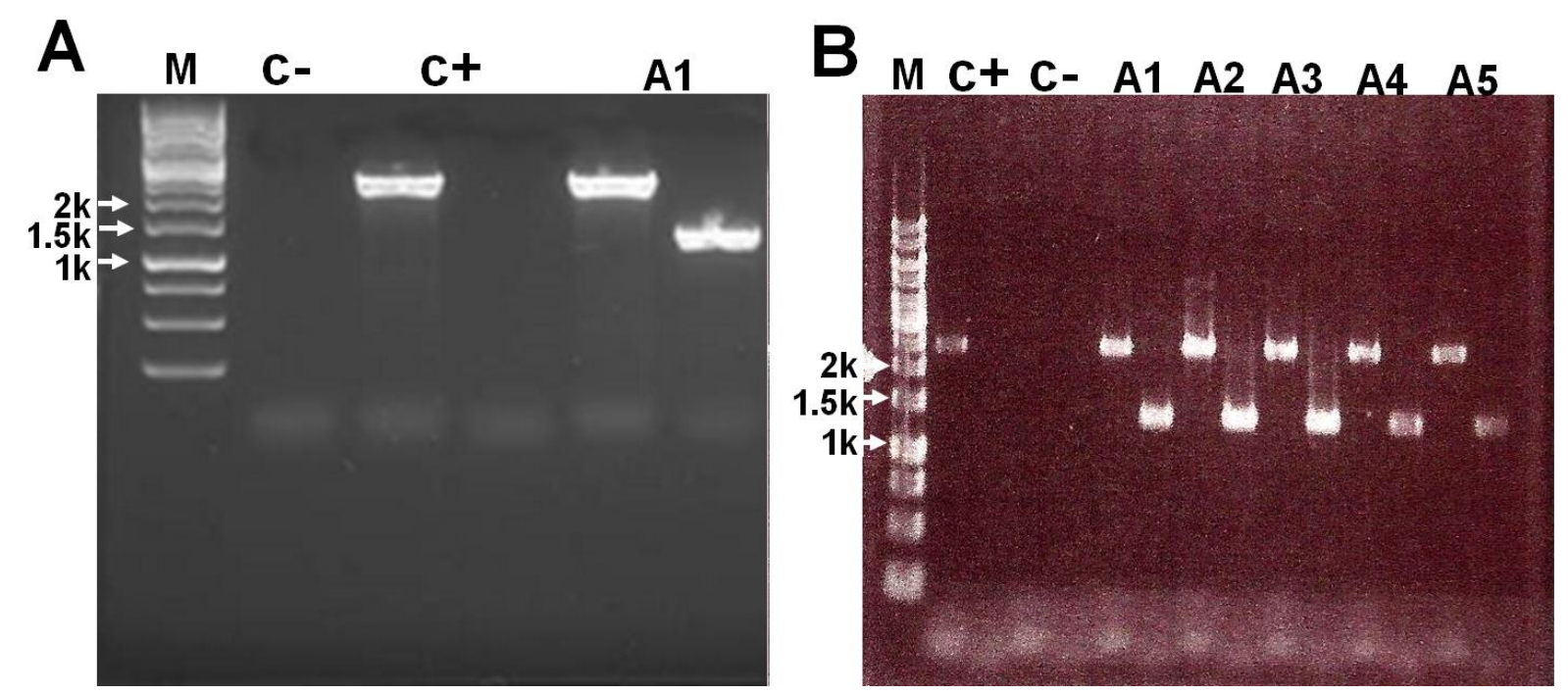

Figura 7. Eletroforese da PCR de confirmação da interrupção do gene SUC2 nas cepas CEN.PK 1023A (A) e CEN.PK 113-6B (B). M: Marcador 1kb plus ThermoScientific; C-: Água; C+: Cepa parental; An: amostras de cepas após transformação com KanMX e seleção em meio contendo geneticina.

\subsubsection{Análise de crescimento em sacarose}

A interrupção de SUC2 foi feita para que a sacarose entre intacta na célula e sofra ação da enzima sacarose fosforilase, com o objetivo de direcionar a utilização da glicose contida nesse substrato para a via de produção de dTDP-Rha. Com o objetivo de avaliar o efeito da interrupção desse gene na taxa de crescimento das cepas, a cepa $\mathrm{RH} 1$ passou por testes de crescimento em sacarose. Como pode ser visto na Figura $8, \mathrm{RH} 1$ mostrou uma taxa de crescimento específica mais lenta, aproximadamente $85 \%$ da taxa de sua cepa parental. Esse comportamento era esperado, visto que o principal gene de metabolização de sacarose foi silenciado. Porém, apesar de não possuir o gene SUC2 funcional, a cepa ainda é capaz de crescer em sacarose. Isso pode ser explicado devido à presença do gene constitutivo MAL2-8c nos genótipos das linhagens RH1 e RL1, que as torna capaz de hidrolisar sacarose, já que esse dissacarídeo pode ser internalizado por transportadores de maltose e ser hidrolisado pela maltase ( $\alpha$-glucosidase) (Mwesigye et al., 1996). No entanto, deve ser enfatizado que a presença de MAL2-8c pode não representar um grande problema de desvio do fluxo metabólico pela enzima maltase, pois a afinidade da sacarose fosforilase $(\mathrm{Km} 13 \mathrm{mM})$ pela sacarose é bem maior que a da maltase $(\mathrm{Km}$ 116-191mM) (Mieyal et al., 1972; Deng et al., 2014). Dessa forma, a sacarose deveria 
ser, em sua maior parte, convertida pela sacarose fosforilase em glicose-1-fosfato e frutose.

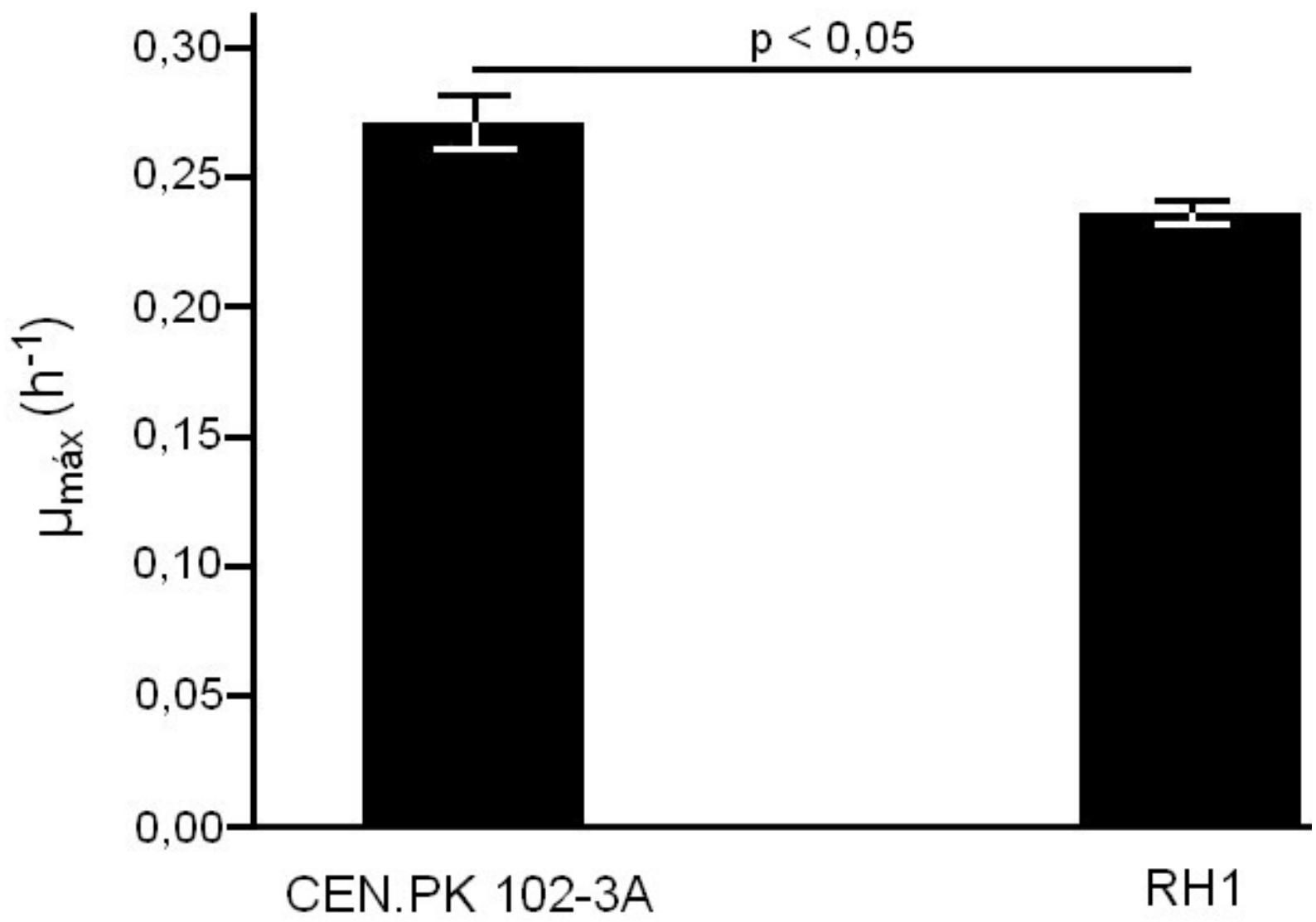

Figura 8. Taxas de crescimento específico máximas ( $\mu_{\text {máx }}$ ) da cepa $\mathrm{RH} 1$ e sua cepa parental CEN.PK 102-3A. Aplicando o teste T para os valores de taxa de crescimento, obtém-se que o $\mu$ de RH1 é menor que $o \mu$ de CEN.PK 103-2A com uma confiança maior que $99 \%(p=0,007)$.

\subsubsection{Atividade de RmIA}

Após a análise de crescimento acima, a cepa $\mathrm{RH} 1$ foi transformada com 0 plasmídeo pGAC, resultando na cepa intermediária $\mathrm{RH} 4$, ou com o plasmídeo p425GPD vazio, resultando na cepa intermediária de referência $\mathrm{RH} 2$ (Tabela 7). Para verificar se os genes estavam sendo expressos antes de continuar com a transformação dos outros plasmídeos, a atividade da enzima RmIA foi testada baseando-se no acúmulo de seu produto dTDP-D-glicose nos extratos das cepas $\mathrm{RH} 2$ e RH4 utilizando sacarose como substrato. Por possuir os genes da sacarose fosforilase e RmIA, mas não RmIB, espera-se que o extrato da cepa $\mathrm{RH} 4$ acumule 
dTDP-D-glicose, diferentemente da cepa referência $\mathrm{RH} 2$ que não possui nenhum dos genes supracitados. Como esperado, a Figura 9 mostra que RH4 apresenta atividade enzimática para $\mathrm{RmIA}$ quase três vezes maior que $\mathrm{RH} 2$, indicando que os genes contidos nos plasmídeos epissomais estão sendo funcionalmente expressos.

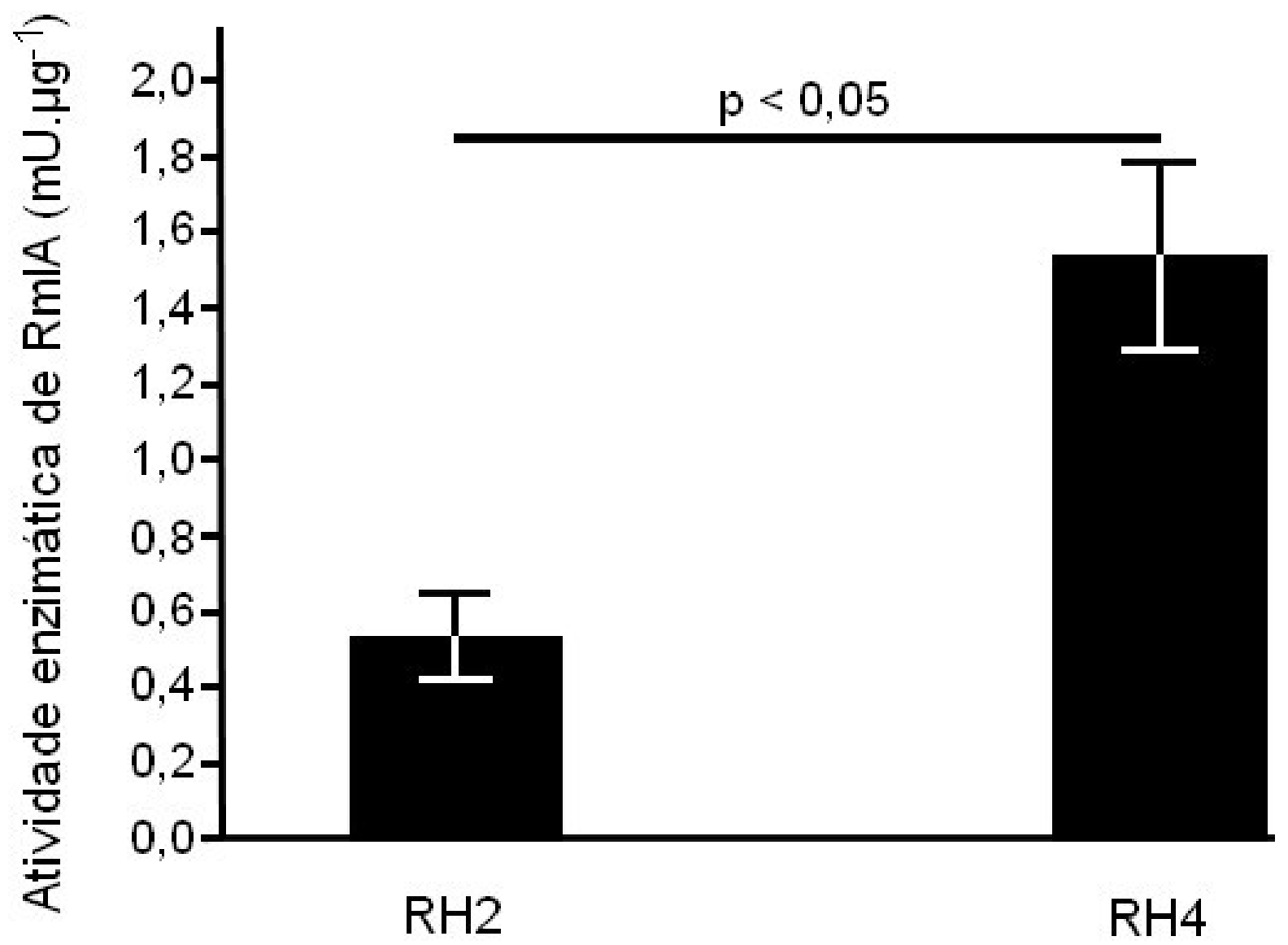

Figura 9. Atividades enzimáticas de RmIA para as cepas intermediárias $\mathrm{RH} 2$ e $\mathrm{RH} 4$ utilizando sacarose como substrato. Aplicando o teste $T$ para os valores de atividade enzimática, obtém-se que a atividade em RH4 é maior que a atividade em RH2 com uma confiança maior que 99\% ( $p=0,005)$.

Em contrapartida, quando o mesmo experimento é realizado utilizando-se glicose-1-fosfato como substrato, as cepas não mostram diferença significativa de atividade de RmIA como pode ser visto na Figura 10.

Esse resultado pode ser explicado pelo fato de que, quando sacarose é utilizada como substrato, além de fornecer glicose-1-fosfato, ela também fornece frutose, que pode ser utilizada na glicólise. Quando glicose-1-fosfato é usada como substrato, é a única fonte de carbono disponível na reação, então a glicólise compete 
com RmIA pelo substrato. O redirecionamento de glicose-1-fosfato para a glicólise é feito por isoenzimas fosfoglicomutases (PGMs) (Figura 4), nativas em S. cerevisiae. Essas enzimas são responsáveis pela interconversão de glicose-1-fosfato em glicose6-fosfato. A PGM2, isoenzima mais relevante responsável por 80-90\% da atividade de PGM em levedura, possui alta afinidade por glicose-1-fosfato, reportada em 23,4 $\mu \mathrm{M}$ (Daugherty et al., 1975). Ainda não foi medida a afinidade da RmIA de $P$. aeruginosa pelo mesmo substrato, mas é razoável concluir que boa parte da glicose-1-fosfato está sendo consumida pelas PGMs para alimentar a via glicolítica. Assim, a atividade de RmlA em RH4 usando esse substrato é virtualmente indetectável.

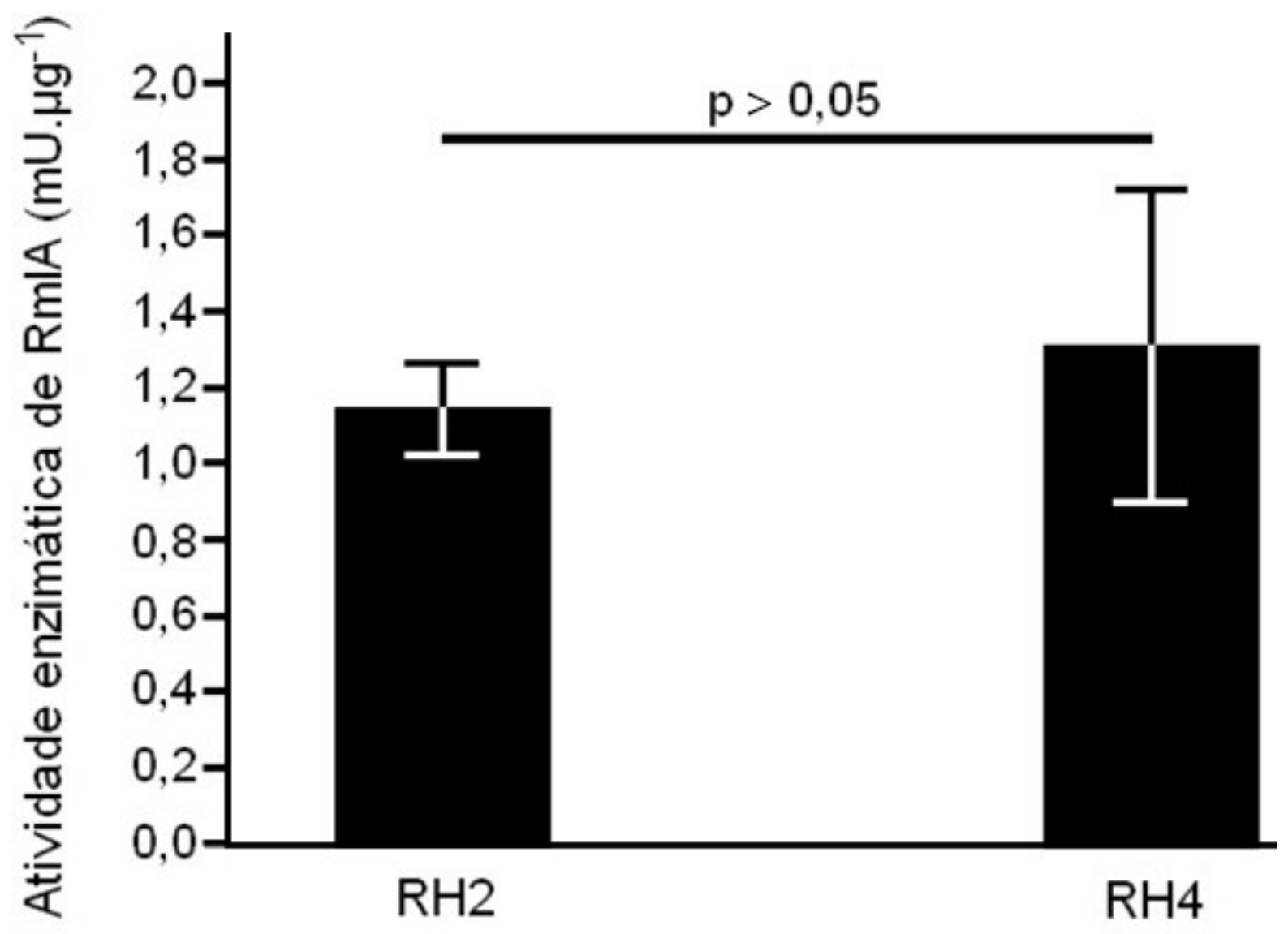

Figura 10. Atividades enzimáticas de RmIA para as cepas intermediárias $\mathrm{RH} 2$ e RH4 utilizando glicose1 -fosfato como substrato. Aplicando o teste T para os valores de atividade enzimática, obtém-se que a atividade em RH4 é igual à atividade em $\mathrm{RH} 2(p=0,3)$. 


\subsubsection{Cepas finais}

Após a detecção da atividade enzimática de RmIA e inferência de que as outras enzimas também estão sendo expressas, seguiram-se as transformações das cepas intermediárias com os plasmídeos restantes, resultando nas cepas finais produtoras de dTDP-Rha (RHP) e mono-RLs (RLP), assim como suas cepas referências contendo os plasmídeos vazios (RHR e RLR, respectivamente) (Tabela 7). Como esperado, além de serem capazes de crescer na presença de geneticina devido a KanMX, as cepas finais são capazes de crescer em meio mínimo com sacarose sem complementação nutricional, indicando que os plasmídeos estão presentes complementando a auxotrofia das cepas.

\subsection{INIBIÇÃO DE CRESCIMENTO POR LÍTIO}

Como já citado anteriormente, as isoenzimas PGMs interconvertem glicose-1$P($ G1P) em glicose-6-P (G6P) (Figura 4). Essas enzimas possuem alta afinidade por G1P $(23,4 \mu \mathrm{M})$ e equilíbrio de reação favorecendo a formação de G6P para alimentar a via glicolítica. Consequentemente, as PGMs competem com a enzima RmIA, primeira da via de síntese de dTDP-Rha (Figura 2), pela G1P disponível. No sentido de tentar direcionar a utilização de G1P para produção de dTDP-Rha, decidiu-se testar se a inibição de PGMs aumentava a produção dessa molécula. Estudos prévios reportam que o lítio é um inibidor de PGM de alta afinidade, apresentando um IC 50 (metade da concentração de inibição máxima) de $0,2 \mathrm{mM}$ in vitro (Masuda et al., 2001). Ademais, em cultivo de levedura com galactose como fonte de carbono, a atividade de PGM é indispensável para o metabolismo da célula, já que esse substrato é transformado em glicose-1-P e sua única via de entrada na via glicolítica é pela atividade de PGM. Ao ser cultivada na presença de galactose e LiCl (Cloreto de lítio) $15 \mathrm{mM}$ em meio líquido, a taxa fermentativa de $S$. cerevisiae, calculada pela quantidade de etanol produzido por tempo de fermentação e peso seco, decai em 90\%, demonstrando a quase completa inibição de PGM por essa concentração de lítio (Masuda et al., 2001). Entretanto, também se sabe que as cepas de levedura da família CEN.PK são hipersensíveis a lítio, mostrando uma diminuição de $65 \%$ na taxa 
de crescimento específica quando cultivadas em meio contendo LiCl a 20mM (DaranLapujade et al., 2009).

Por esse motivo, curvas de crescimento na presença e ausência de $\mathrm{LiCl}$ a 15 $\mathrm{mM}$ foram realizadas com as cepas RHR e RHP crescidas em sacarose para avaliar o nível de toxicidade desse composto. Como pode ser observado na Figura 11, tanto a cepa referência quanto produtora mostraram crescimento prejudicado quando da presença de lítio, reduzindo suas taxas de crescimento específico máximas para $82 \%$ e $88 \%$, respectivamente, das taxas quando cultivadas sem lítio. Entretanto, esses valores não foram tão expressivos quanto os encontrados por Daran-Lapujade et al. (2009), onde a cepa reduziu sua taxa para $35 \%$ da original quando cultivada na presença de $\mathrm{LiCl} 20 \mathrm{mM}$. Desse modo, tornam-se viáveis futuras análises de produção de dTDP-Rha e mono-RLs na presença e ausência de lítio, já que a presença desse não prejudica tão expressivamente o crescimento das cepas e pode, potencialmente, aumentar a produção dos compostos de interesse.

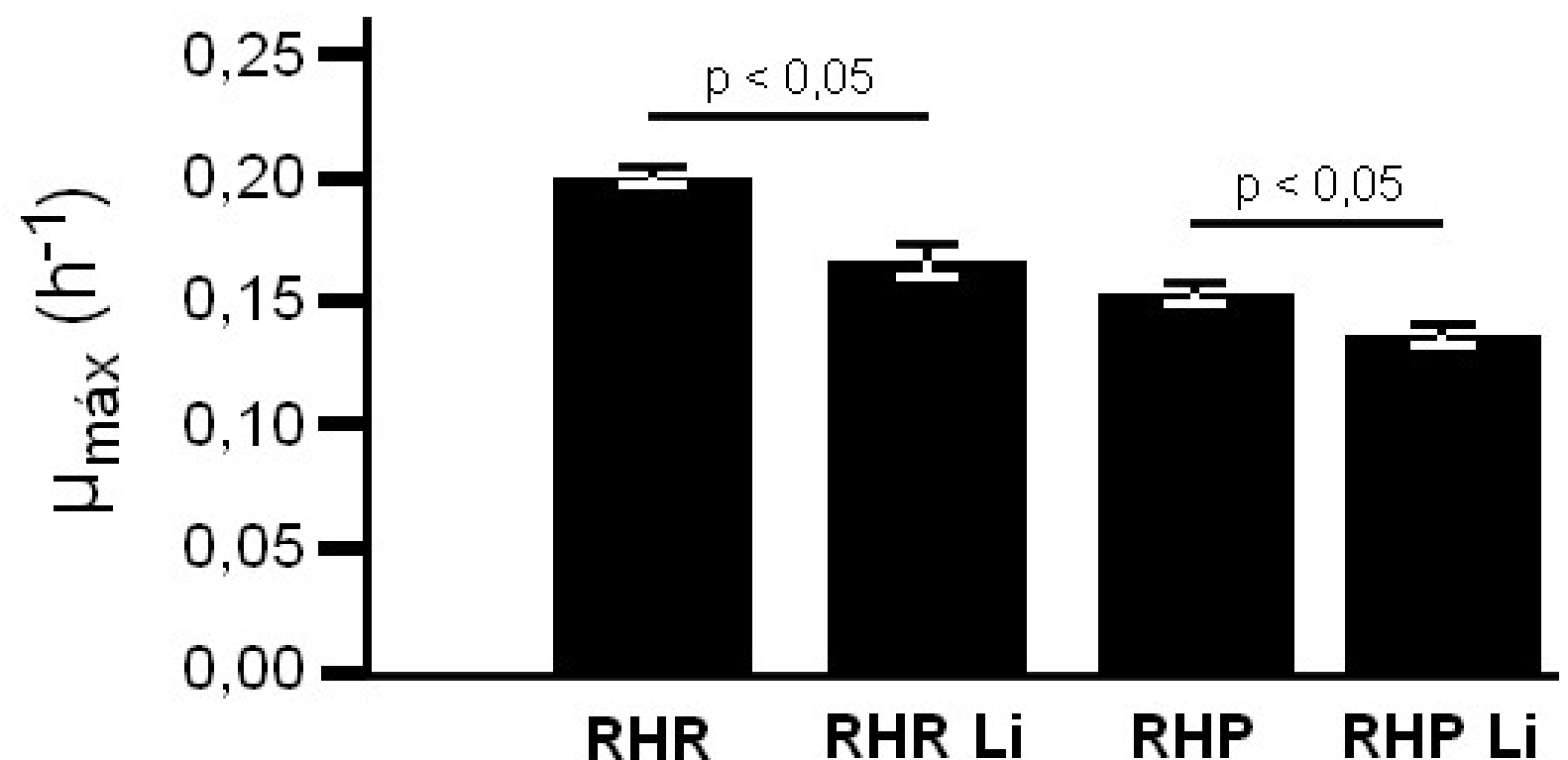

Figura 11. Taxas de crescimento específico máximas ( $\mu_{\text {máx }}$ ) das cepas RHR e RHP crescidas em sacarose na ausência e presença de LiCL $15 \mathrm{mM}$. Aplicando o teste T, obtém-se que os valores de $\mu$ tanto de RHR quanto de RHP crescidas na presença de lítio são significativamente menores quando comparados com a condição de ausência de lítio ( $p=0,006$ e 0,026, respectivamente). 


\subsection{DETECÇÃO DE DTDP-L-RAMNOSE}

\subsubsection{HPAEC}

Após ensaios de crescimento com $\mathrm{LiCl} 15 \mathrm{mM}$, avaliou-se a produção de dTDPRha pela cepa RHP, usando RHR como controle negativo, crescidas na presença e na ausência de lítio. Para tal, decidiu-se testar a sensibilidade do método de HPAEC para detecção de açúcares-nucleotídeos descrito por Köplin et al. (1997). Amostras puras de dTDP-Rha a 0, 5, 20, 50, 70 e $100 \mathrm{mg} / \mathrm{L}$ foram analisadas para criar uma curva padrão baseada no método descrito sem alterações, resultando em uma curva que, após regressão linear, apresentou coeficiente de determinação $\left(R^{2}\right)$ de 99,96\%. Com este resultado promissor, pequenos ajustes na concentração da fase móvel, na temperatura da coluna e na faixa de comprimento de onda para detecção de dTDPRha foram realizados de modo a estender o tempo de eluição e aumentar o sinal de detecção dessa molécula.

Com o método modificado estabelecido, protocolos de extração de dTDP-Rha de lisados celulares foram testados. Inicialmente, o método de etanol fervente para extração geral de metabólitos (González e Franc, 1997) foi testado com as cepas RHR e RHP, resultando em amostras com cromatogramas complexos e com baixa resolução, gerando resultados inconclusivos (dados não mostrados). Dessa maneira, decidiu-se testar um método mais específico para purificação de açúcaresnucleotídeos, descrito por Räbinä et al. (2001), baseado em Extração em Fase Sólida com colunas de carbono grafitizado. Os autores afirmam que a recuperação dessas moléculas após extração é de 93 a 100\%, estando elas em solução pura ou adicionadas em extrato celular de levedura, demonstrando a eficiência e seletividade do método.

Para avaliar o sucesso do método em nosso laboratório, experimentos de SPE

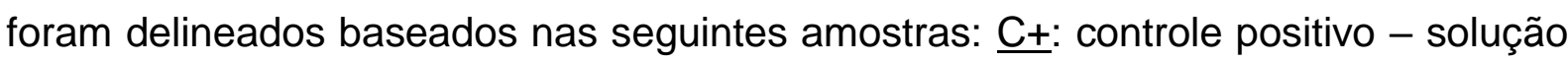
pura de dTDP-Rha $100 \mathrm{mg} / \mathrm{L}$; $\underline{\mathrm{RHR}}$ : extrato da cepa RHR; $\underline{\text { IS: }}$ : padrão interno - extrato de RHR adicionado de dTDP-Rha para $100 \mathrm{mg} / \mathrm{L}$; RHP: extrato da cepa RHP; RHPLi: extrato da cepa RHP crescida na presença de $\mathrm{LiCl} 15 \mathrm{mM}$. Com essas amostras, avaliou-se a recuperação, após SPE, de dTDP-Rha em solução pura $\left(\mathrm{C}_{+}\right)$e quando 
adicionada na cepa referência (IS), com a finalidade de descobrir se as moléculas presentes nos extratos celulares influenciavam na eficiência de extração de dTDPRha. Além disso, avaliou-se a produção de dTDP-Rha pela cepa RHP crescida na presença e ausência de lítio, utilizando RHR como referência.

Após sucessivas tentativas de extração por SPE e detecção por HPAEC, a recuperação de dTDP-Rha em solução pura após extração foi menor que a descrita por Räbinä et al. (2001), variando de 40 a 70\%. Ademais, diferentemente do que foi previamente descrito, não foi possível detectar dTDP-Rha quando essa foi adicionada ao extrato da cepa RHR, demonstrando que o extrato interfere na extração dessa molécula (dados não mostrados). Ainda, também não foi detectada a presença dessa molécula nas amostras da cepa RHP. Esses resultados mostraram-se inconclusivos, já que o método de extração não foi eficiente nem para recuperar dTDP-Rha adicionada a extrato celular. Dessa maneira, não se sabe se a cepa RHP não produz dTDP-Rha ou se ela está sendo perdida durante o método de extração.

Após a falha no estabelecimento dos métodos de extração e detecção descritos acima, procurou-se uma metodologia alternativa para a detecção de dTDP-Rha.

\subsubsection{MS/MS}

Inicialmente, os experimentos de MS e MS/MS foram otimizados utilizando uma solução padrão de dTDP-L-ramnose. O melhor modo de ionização foi o negativo ESI()-MS e os parâmetros voltagem do cone, energia de colisão e $\mathrm{m} / \mathrm{z}$ do íon precursor e fragmento foram configurados no modo MRM. O MS triplo quadrupolo operado em modo MRM é uma análise mais sensível e seletiva, uma vez que é possível escolher qual precursor iônico será fragmentado e qual fragmento será detectado. O íon precursor ( $\mathrm{m} / \mathrm{z} 547.3$ ) foi selecionado no primeiro quadrupolo (Q1), colidido com gás no segundo quadrupolo para ser fragmentado (Q2) e, então, o fragmento iônico de interesse ( $\mathrm{m} / \mathrm{z} 321)$ foi detectado no terceiro quadrupolo (Q3).

Para a análise das amostras de RHR e RHP, extratos celulares foram preparados utilizando-se método de etanol fervente em triplicata. As amostras foram ressuspendidas em água e analisadas por UPLC-MS/MS. Nas análises feitas para a cepa produtora (RHP), um composto é eluído com o tempo de 3.86 minutos com transição de MRM de 547.3 > 321 que pode ser atribuído a dTDP-L-ramnose (Turnock 
e Ferguson, 2007; Feng et al., 2016). Para a cepa controle (RHR) as análises não mostraram nenhum composto com essa transição de MRM, nem com o peso molecular correspondente à dTDP-L-ramnose (Figura 12).

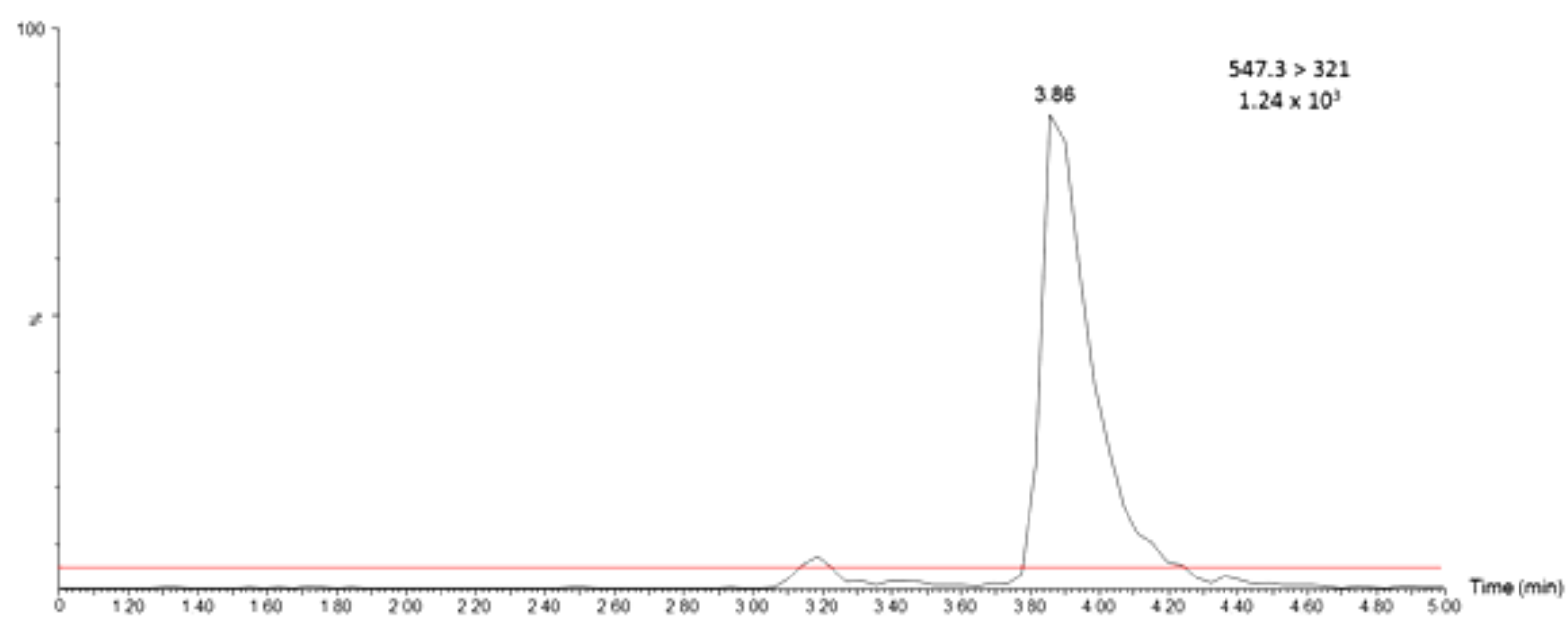

Figura 12. Sobreposição dos resultados de MRM da cepa controle RHR (linha vermelha) e da cepa produtora RHP (linha preta).

Todas as evidências apontam para que o pico de detecção em questão seja referente à dTDP-Rha, apesar de o tempo de retenção da molécula no extrato de RHP não ser igual ao do padrão usado nas análises. Como pode ser visto na Figura 13, o padrão $(A)$ tem tempo de retenção menor que a molécula produzida por RHP (B linha contínua). Esse resultado é confirmado ao adicionar-se padrão de dTDP-Rha ao extrato celular de RHP, resultando na eluição de dois picos de mesma massa e tempo de retenção diferentes (B linha pontilhada). Isso pode ser explicado se levado em consideração que o composto utilizado como padrão nas análises pode não tratar-se do mesmo estereoisômero produzido pela cepa RHP. Ademais, além da massa dos dois picos serem a mesma, a molécula detectada nos extratos de RHP não é observada nos extratos da cepa referência RHR, já que esse composto não é naturalmente produzido em leveduras. Os resultados acimas indicam fortemente a construção bem sucedida de uma cepa de levedura produtora de dTDP-L-ramnose.

Ainda que detectada, a quantidade de dTDP-Rha medida foi muito baixa, inviabilizando sua quantificação. Isso pode ser devido a dois fatores. Como mencionado anteriormente, PGM pode estar competindo com RmIA pela glicose-1fosfato disponível, diminuindo o rendimento de produção de dTDP-Rha. Além disso, 
como previamente descrito (Blankenfeldt et al., 2000), dTDP-Rha apresenta efeito inibitório na atividade de RmIA quando acumulada, diminuindo o fluxo em direção à produção dela mesma. Os resultados e as informações apresentados mostram a necessidade de continuar explorando estratégias de engenharia metabólica em RHP, como deleção de PGM, para aumentar a produção de dTDP-Rha ou torná-la uma cepa produtora de L-ramnose adicionando-se mais etapas enzimáticas para desacoplar o nucleotídeo da ramnose.
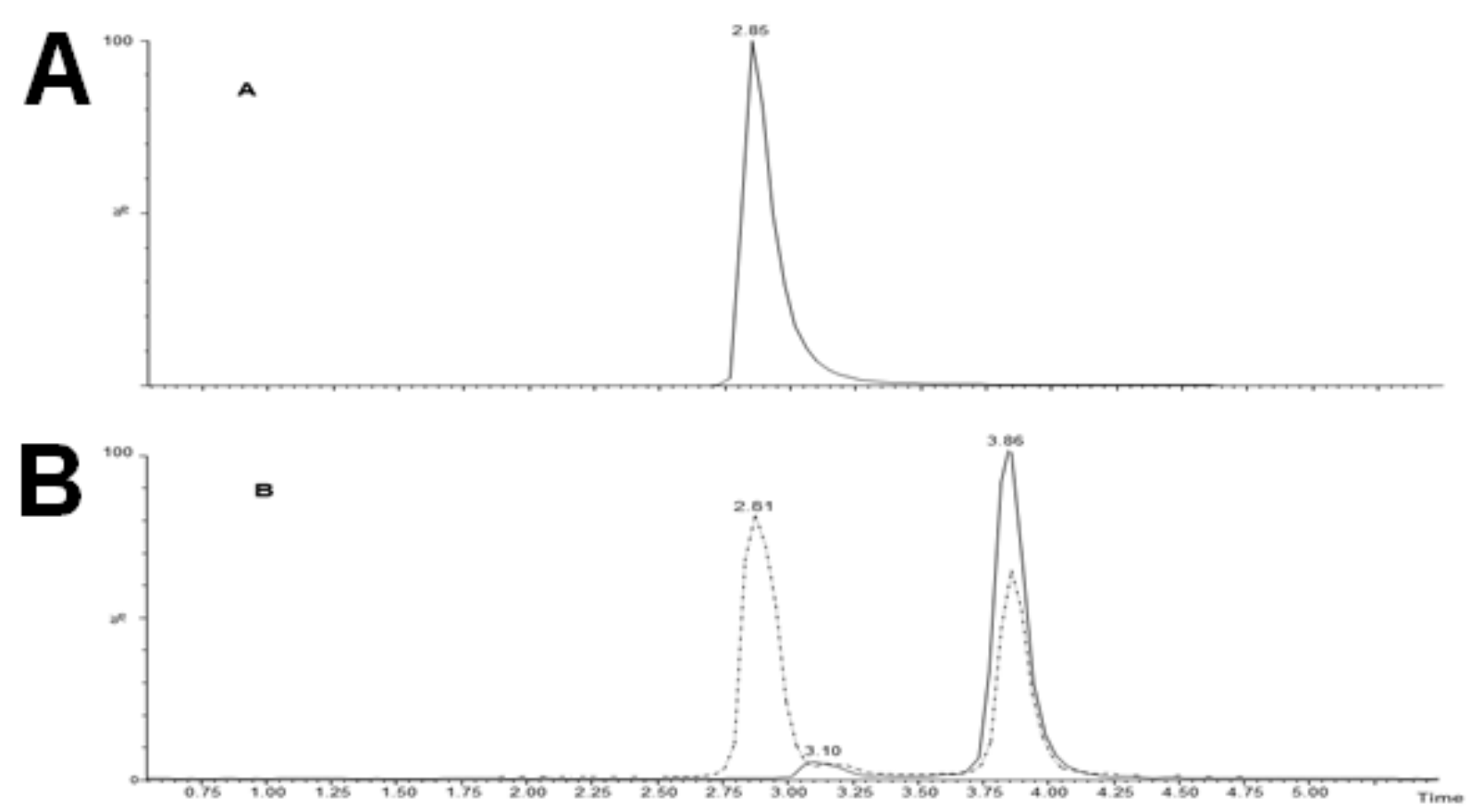

Figura 13. Análise de solução padrão de dTDP-L-ramnose (A), de extrato celular de RHP (B linha contínua) e de extrato celular de RHP adicionado de padrão de dTDP-L-ramnose (B linha pontilhada). 


\subsection{DETECÇÃO DE MONO-RAMNOLIPÍDEOS}

\subsubsection{Ensaio de Orcinol}

Em paralelo com as análises de dTDP-Rha, investigou-se a produção de monoRLs pela cepa RLP. Para tal, o método quantitativo de detecção por orcinol é um dos mais amplamente utilizados, consistindo em aquecer extratos de sobrenadante de culturas contendo RLs em conjunto com ácido sulfúrico e orcinol. Dessa forma, os grupos ramnose dos RLs são hidrolisados e transformados em metil furfural, que por sua vez reagem com orcinol produzindo uma coloração azul-esverdeada, detectada espectrofotometricamente a $421 \mathrm{~nm}$ (Abdel-Mawgoud et al., 2011). Normalmente, em culturas bacterianas, os RLs são produzidos e secretados para o meio extra celular. Assim, realiza-se uma extração com solvente orgânico do sobrenadante das culturas para obter-se os RLs. No caso desse estudo, os mono-RLs são produzidos e armazenados intracelularmente. Dessa maneira, precisou-se avaliar a eficácia do método de detecção por orcinol utilizando amostras de extratos obtidos por dietil-éter a partir de extratos celulares da cepa RLP, onde espera-se que haja muito mais moléculas orgânicas quando comparados a sobrenadantes de culturas.

A princípio, foi realizada uma curva padrão utilizando soluções puras de dTDPRha a 0, 5, 10, 20, 50 e $80 \mathrm{mg} / \mathrm{L}$, em triplicata, para avaliar a sensibilidade do método. Obteve-se uma curva que, após regressão linear, apresentou $R^{2}$ de 99,52\%, atestando a precisão do método. Em seguida, experimento foi delineado para avaliar a eficácia do método de lise química por detergente das células de levedura seguido por método de extração pelo solvente orgânico éter etílico. Para tal, as seguintes

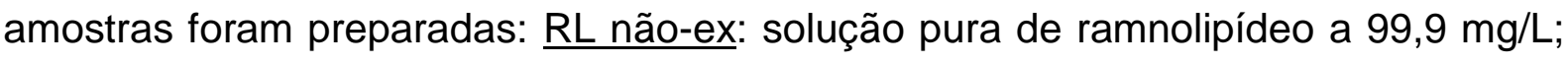
RL ex: solução pura de ramnolipídeo a 99,9 mg/L submetida a processo de extração por solvente orgânico; RLR: extrato celular da cepa RLR submetido a processo de extração por solvente orgânico; $\underline{R L R+R L}$ : extrato celular da cepa RLR adicionado de RLs para 99,9 mg/L submetido a processo de extração por solvente orgânico; $\underline{R L P}$ : extrato celular da cepa RLP submetido a processo de extração por solvente orgânico. À partir da comparação dos dados de ensaio de orcinol gerados pelas amostras RL não-ex e RL ex, esperava-se avaliar a recuperação de RLs pelo método de extração 
com éter-etílico. À partir das amostras $R L R$ e $R L R+R L$, esperava-se investigar se o extrato celular da cepa referência interferia na extração de RLs. Finalmente, esperavase obter uma quantificação de RLs produzidos pela cepa RLP pela comparação entre as amostras RLR e RLP. Após algumas tentativas e aperfeiçoamento da técnica, os dados obtidos dos experimentos de detecção de RLs por orcinol podem ser vistos na Tabela 8. A recuperação após extração de RLs em solução pura foi de $92,75 \%$, enquanto que a recuperação de RLs em extratos celulares foi de 90,54\%, indicando que a extração por éter etílico é eficiente. Entretanto, ao analisar-se os dados das amostras RLR e RLP, percebe-se que a cepa referência gerou sinal quase duas vezes maior que a cepa produtora, indicando a sensibilidade do método aos outros compostos extraídos em conjunto pelo solvente orgânico. Esse resultado é inconclusivo, pois não é possível resolver se a cepa RLP não está produzindo RLs ou se a quantidade produzida não é o suficiente para se destacar dentre os compostos extraídos em conjunto. Para fins comparativos, o barulho de fundo gerado pelos compostos extraídos do extrato de RLR é similar ao sinal gerado pelo padrão de dTDP-Rha a 50 mg/L, concentração já alta desse composto.

Tabela 8. Resultado do ensaio de orcinol para detecção de RLs. ${ }^{*}$ Calculado como (RL ex / RL nãoex $)^{*} 100 .{ }^{* *}$ Calculado como $\left\{[(R L R+R L)-R L R] / R L\right.$ não-ex ${ }^{*} 100$.

\begin{tabular}{ccc}
\hline Amostra & Concentração (mg/L) & Recuperação (\%) \\
\hline RL não-ex & 157,34 & - \\
RL ex & 145,93 & $92,75 \%$ * \\
RLR+RL & 201,46 & $90,54 \%$ ** \\
RLR & 59,03 & - \\
RLP & 34,85 & - \\
\hline
\end{tabular}

Devido à falha no estabelecimento dos métodos de extração e detecção acima, procurou-se uma nova metodologia para detectar a produção de mono-RLs por RLP. 


\subsubsection{Microscopia Confocal}

Para a detecção de mono-ramnolipídeos, as cepas RLR e RLP foram submetidas a microscopia de fluorescência para detecção de acúmulo lipídico intracelular corado com BJL16\#UnB3, corante produzido e patenteado pelo grupo do Prof. Dr. José Corrêa Raimundo da Universidade de Brasília. Visualmente, é possível observar diferença significativa na quantidade de lipídeos armazenada por RLR e RLP (Figura 14-A e -C, respectivamente). A cepa referência mostrou, quando comparada com a cepa produtora, menor acúmulo de lipídeos nos corpos lipídicos, menos corpos lipídicos por célula e menor quantidade de células contendo corpos lipídicos por amostra. As Figura 14-B e -D de contraste de fase mostram o aspecto morfológico normal das células das cepas RLR e RLP, respectivamente, submetidas ao processo de coloração, além de mostrar que ambas as amostras encontram-se em concentrações similares. 


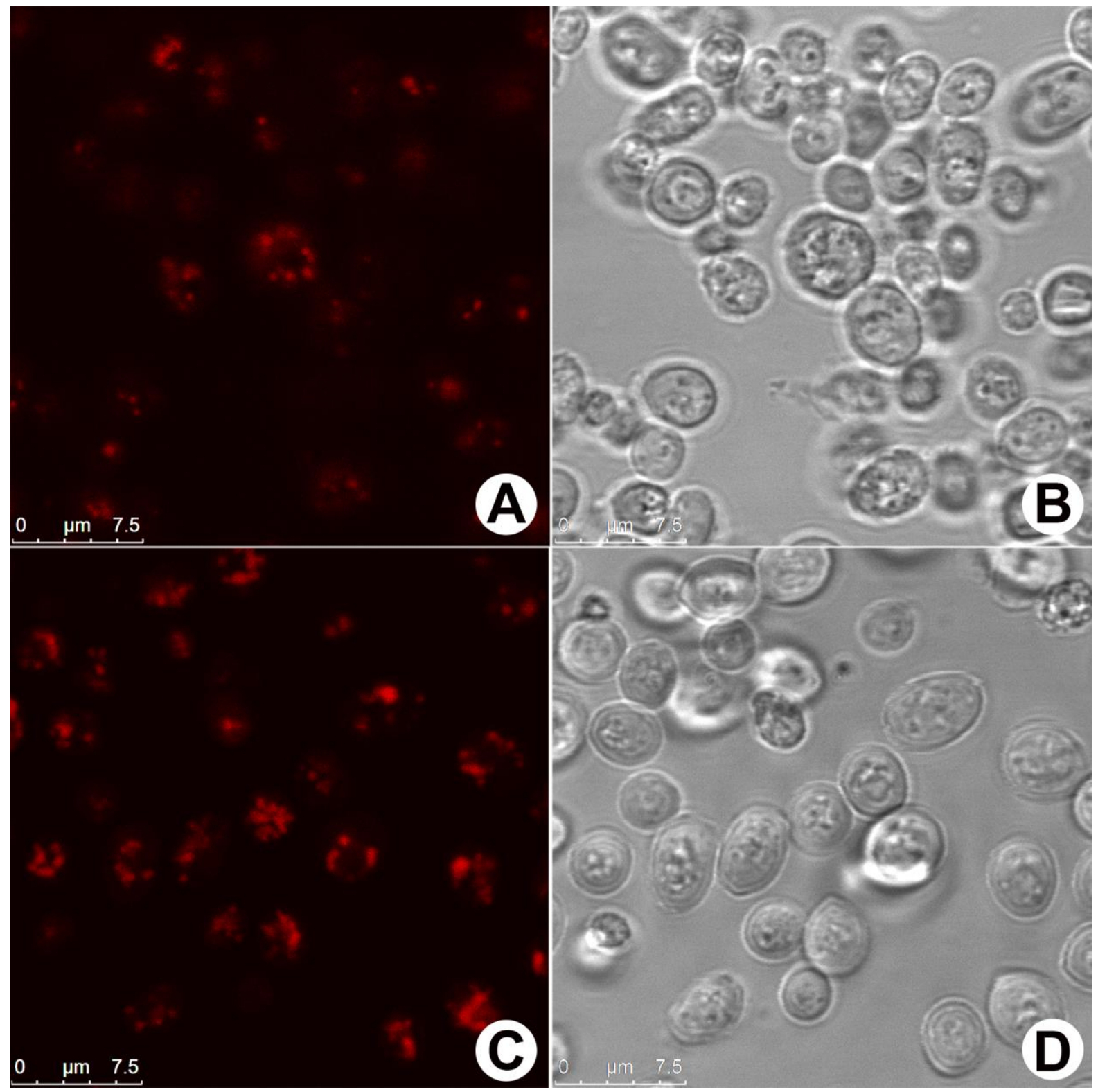

Figura 14. Microscopias de fluorescência e contraste de fase das cepas $R L R$ ( $A$ e $B$, respectivamente) e RLP ( $C$ e D, respectivamente). As imagens A e C mostram gotículas lipídicas coradas acumuladas nas cepas RLR e RLP, respectivamente. As imagens $B$ e D mostram o aspecto morfológico normal das amostras de RLR e RLP, respectivamente.

Esses resultados foram confirmados por quantificação celular, que mostrou um aumento de aproximadamente $40 \%$ no número de células da cepa produtora contendo corpos lipídicos quando comparada com a cepa referência (Figura 15-A). Ademais, o número de corpos lipídicos por célula é quase duas vezes maior na cepa produtora quando (Figura 15-B). 

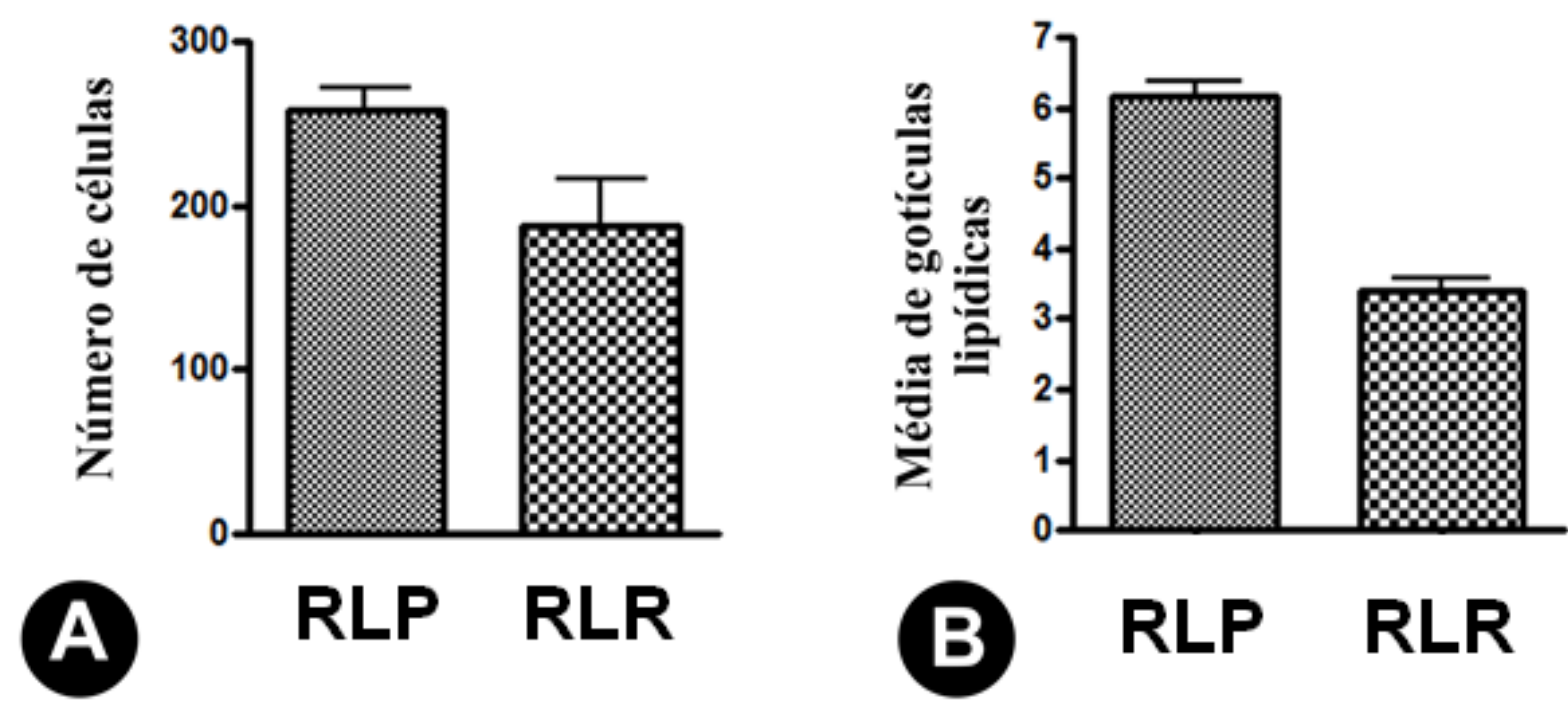

Figura 15. Quantificação de células contendo gotículas lipídicas $(A)$ e de número de gotículas lipídicas por célula (B) das cepas RLR (referência) e RLP (produtora).

A análise de intensidade de fluorescência corroborou os resultados obtidos acima. A Figura 16 mostra os perfis de emissão de fluorescência associados às cepas RLR e RLP ( $A$ e $B$, respectivamente). Esses perfis estão intimamente relacionados à quantidade de lipídeos armazenada em cada cepa. As imagens térmicas claramente indicam o número elevado de corpos lipídicos e de lipídeo por corpo lipídico na cepa $R L P$ quando comparada à $R L R$ (C e D, respectivamente). Finalmente, os histogramas também indicam, indiretamente, uma maior acumulação lipídica na cepa produtora em comparação com a cepa referência (E e F, respectivamente). 

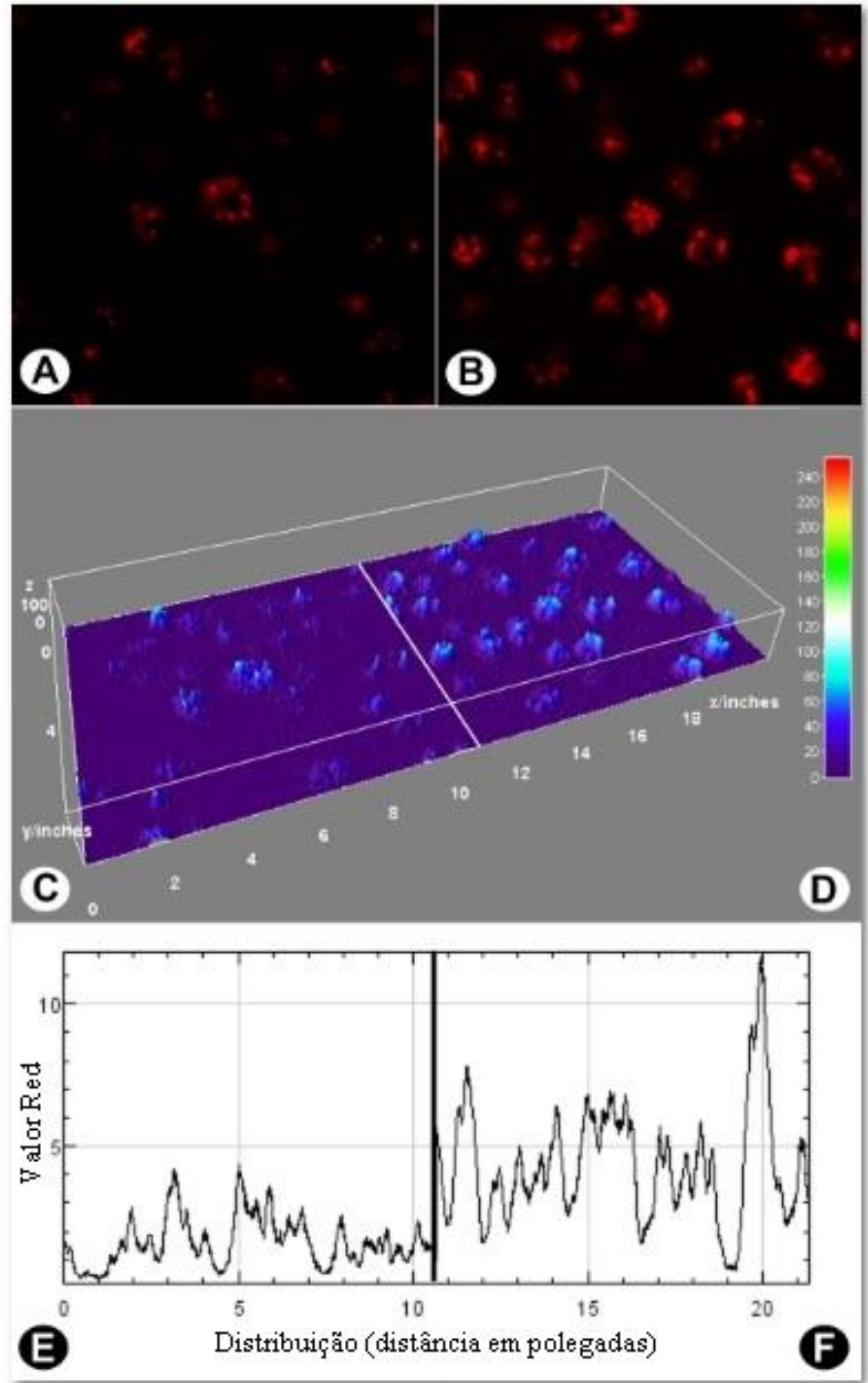

Figura 16. Quantificação do sinal de fluorescência. As imagens A e B mostram o perfil de fluorescência das cepas RLR e RLP, respectivamente. As imagens C e D mostram o perfil tridimensional da representação térmica dos valores de pixel obtidos das imagens LUT. As imagens $E$ e $F$ mostram o histograma relacionado ao valor de pixel obtido das imagens LUT. 
Os resultados apresentados acima são apenas indicações indiretas da produção de mono-RLs, já que o que confirmam é um maior acúmulo de lipídeos intracelularmente. Técnicas específicas para detecção e quantificação de RLs devem ser exploradas para confirmar definitivamente a produção de mono-RLs por RLP.

Além de dTDP-Rha, as enzimas RhIA e B utilizam beta-hidroxiacil-ACP para a síntese de RLs (Figura 2). Beta-hidroxiacil-ACP é intermediário da via de síntese de ácidos graxos de novo já presente na levedura, e pode ser alvo de estratégias de engenharia metabólica para aumento de produção a fim de aumentar a produção de RLs. Nesse sentido, Tang et al. (2015) compilaram os recentes avanços em engenharia metabólica de $S$. cerevisiae para aumentar o fluxo metabólico na via de síntese de ácidos graxos, sendo algumas estratégias: aumentar a produção de acetilCoA e malonil-CoA, precursores da via de síntese de ácidos graxos; inibir ou reduzir o fluxo nas vias de glicerol e etanol que competem pela fonte de carbono; atenuar regulação negativa da via por produtos dessa; bloquear beta-oxidação; aumentar concentrações intracelulares de NADPH, necessários como poder redutor na síntese de ácidos graxos. Como pode-se perceber, há diversos avanços na engenharia metabólica de $S$. cerevisiae para aumentar a produção de ácidos graxos, decorrentes principalmente da demanda de produção de biocombustíveis à partir de ácidos graxos em levedura (Tang et al., 2015). Assim, o presente estudo focou primeiramente na inserção dos genes exógenos de $P$. aeruginosa em $S$. cerevisiae para adicionar a parte da via de síntese de RLs que essa ainda não possuía. 


\section{CONCLUSÃO}

O presente estudo demonstrou, como prova de conceito pela primeira vez, que a levedura Saccharomyces cerevisiae pode ser geneticamente modificada para se tornar produtora de ramnose e ramnolipídeos. $\mathrm{O}$ foco atual da pesquisa segue em buscar definir os parâmetros cinéticos das cepas produzidas nesse estudo, procurando quantificar rendimentos e produtividades dos compostos de interesse. Dessa maneira, é possível obter informações sobre gargalos na produção, levando a futuras estratégias para aumentar a eficiência dos biocatalisadores. As estratégias apresentadas nesse trabalho são desenvolvimentos importantes no sentido de melhorar a produção industrial de ramnolipídeos utilizando um substrato renovável pouco dispendioso e um hospedeiro não-patogênico.

Extrapolando os âmbitos da pesquisa, o presente estudo me foi de bastante enriquecimento profissional. Nele tive a oportunidade de trabalhar com técnicas diversas e relevantes no meio científico, como cromatografias variadas e espectrometria de massas. Ademais, me foi oferecida a oportunidade de trabalhar na Universidade Chalmers de Tecnologia na Suécia, em laboratório de relevância acadêmica internacional, ponto chave para aquisição de expertise e networking. Finalmente, concluo um Mestrado produtivo, com patente e manuscrito em redação, ponto importante não apenas para minha carreira científica, mas também para o Programa de Pós-Graduação em Biologia Molecular que me ofereceu uma ótima estrutura para que eu pudesse realizar meus estudos. 


\section{BIBLIOGRAFIA}

ABDEL-MAWGOUD, A. M. et al. Rhamnolipids: Detection, analysis, biosynthesis, genetic regulation, and bioengineering of production. In: SOBERÓN-CHAVEZ, G. (Ed.) Biosurfactants: From Genes to applications. Münster: Springer, 2011. p.13-56.

BADOTTI, F. et al. Switching the mode of sucrose utilization by Saccharomyces cerevisiae. Microbial Cell Factories, v. 7, n. 1, p. 4, 2008.

BAILEY, J. E. Toward a science of metabolic engineering. Science, v. 252, n. 5013, p. 1668-75, 1991.

BANAT, I. M. Biosurfactants production and possible uses in microbial enhanced oil recovery and oil pollution remediation: A review. Bioresource Technology, v. 51, n. 1, p. 1-12, 1995.

BANAT, I. M.; MAKKAR, R. S.; CAMEOTRA, S. S. Potential commercial applications of microbial surfactants. Applied microbiology and biotechnology, v. 53 , n. 5, p. 495-508, 2000.

BASSO, T. O. et al. Engineering topology and kinetics of sucrose metabolism in Saccharomyces cerevisiae for improved ethanol yield. Metabolic Engineering, v. 13, n. 6, p. 694-703, 2011.

BATISTA, A. S.; MILETTI, L. C.; STAMBUK, B. U. Sucrose fermentation by Saccharomyces cerevisiae lacking hexose transport. Journal of Molecular Microbiology and Biotechnology, v. 8, n. 1, p. 26-33, 2004.

BLANKENFELDT, W. et al. The structural basis of the catalytic mechanism and regulation of glucose-1-phosphate thymidylyltransferase (RmIA). The EMBO Journal, v. 19, n. 24, p. 6652-6663, 2000. 
BORODINA, I.; NIELSEN, J. Advances in metabolic engineering of yeast Saccharomyces cerevisiae for production of chemicals. Biotechnology Journal, v. 9, n. 5, p. 609-629, 2014.

CABRERA-VALLADARES, N. et al. Monorhamnolipids and 3-(3hydroxyalkanoyloxy)alkanoic acids (HAAs) production using Escherichia coli as a heterologous host. Applied Microbiology and Biotechnology, v. 73, n. 1, p. 187-94, 2006.

CAMEOTRA, S. S.; MAKKAR, R. S. Recent applications of biosurfactants as biological and immunological molecules. Current Opinions on Microbiology, v. 7, n. 3, p. 262266, 2004.

CHRISTOVA, N. et al. Rhamnolipid biosurfactants produced by Renibacterium salmoninarum 27BN during growth on $n$-hexadecane. Zeitschrift fur Naturforschung Section C, v. 59, n. 1-2, p. 70-74, 2004.

DARAN-LAPUJADE, P. et al. An atypical PMR2 locus is responsible for hypersensitivity to sodium and lithium cations in the laboratory strain Saccharomyces cerevisiae CEN.PK113-7D. FEMS Yeast Research, v. 9, p. 789-792, 2009.

DAUGHERTY, J. P.; KRAEMER, W. F.; JOSHI, J. G. Purification and properties of phosphoglucomutase from Fleischmann's yeast. European Journal of Biochemistry, v. 57, n. 1 , p. $115-26,1975$.

DE KOK, S. et al. Increasing free-energy (ATP) conservation in maltose-grown Saccharomyces cerevisiae by expression of a heterologous maltose phosphorylase. Metabolic Engineering, v. 13, p. 518-526, 2011.

DENG, X. et al. Similarities and differences in the biochemical and enzymological properties of the four isomaltases from Saccharomyces cerevisiae. FEBS Open Bio, v. 4, p. 200-12, 2014. 
FENG, L.; SHOU, Q.; BUTCHER, REBECCA A. Identification of a dTDP-rhamnose biosynthetic pathway that oscillates with the molting cycle in Caenorhabditis elegans. Biochemical Journal, v. 473, n. 11, p. 1507-1521, 2016.

FERREIRA, V. F. et al. Potencialidades e oportunidades na química da sacarose e outros açúcares. Química Nova, v. 32, n. 3, 2009.

FUGUET, E. et al. Critical micelle concentration of surfactants in aqueous buffered and unbuffered systems. Analytica Chimica Acta, v. 548, n. 1-2, p. 95-100, 2005.

GONZALEZ, B.; FRANCOIS, J.; RENAUD, M. A rapid and reliable method for metabolite extraction in yeast using boiling buffered ethanol. Yeast, v. 13, n. 14, p. 1347-55, 1997.

GROSSMANN, M. K.; ZIMMERMANN, F. K. The structural genes of internal invertases in Saccharomyces cerevisiae. Molecular and General Genetics MGG, v. 175, n. 2, p. 223-229, 1979.

GÜLDENER, U. et al. A new efficient gene disruption cassette for repeated use in budding yeast. Nucleic Acid Research. v. 24, n. 13, p. 2519-2524, 1996.

GUTIERREZ, M. et al. Simultaneous Inhibition of Rhamnolipid and Polyhydroxyalkanoic Acid Synthesis and Biofilm Formation in Pseudomonas aeruginosa by 2-Bromoalkanoic Acids: Effect of Inhibitor Alkyl-Chain-Length. Plos One, v.8, n. 9, 2013.

HENKEL, M. et al. Rhamnolipids as biosurfactants from renewable resources: Concepts for next-generation rhamnolipid production. Process Biochemistry, v. 47, n. 8, p. 1207-1219, 2012.

HILL, J. et al. DMSO-enhanced whole cell yeast transformation. Nucleic Acids Research, v. 19, n. 20, p. 5791, 1991. 
KÖPLIN, R.; BRISSON, J. R.; WHITFIELD, C. UDP-galactofuranose precursor required for formation of the lipopolysaccharide $\mathrm{O}$ antigen of Klebsiella pneumoniae serotype $\mathrm{O} 1$ is synthesized by the product of the rfbDKPO1 gene. The Journal of Biological Chemistry, v. 272, n. 7, p. 4121-4128, 1997.

KOSCHWANEZ, J. H. et al. Improved use of a public good selects for the evolution of undifferentiated multicellularity. Elife. 2013. Disponível em: <https://elifesciences.org/content/2/e00367>. Acesso em: 28 jan 2017.

LEITERMANN, F. et al. Rhamnolipids. In: TIMMIS, K.N. Handbook of hydrocarbon and lipid microbiology. Heidelberg: Springer-Verlag, 2010. p. 3037-3051.

MADSEN, J. K. et al. The anionic biosurfactant rhamnolipid does not denature industrial enzymes. Frontiers in Microbiology, v. 6, p. 292, 2015.

MARCHANT, R.; BANAT, I. M. Microbial biosurfactants: challenges and opportunities for future exploitation. Trends in biotechnology, v. 30, n. 11, p. 558-565, 2012.

MARKETSANDMARKETS. Surfactants market by type (anionic, non-ionic, cationic, and amphoteric), substrate (synthetic, and bio- based), application (detergents, personal care, textile, elastomers and plastics, crop protection, food and beverage) Global forecast to 2021.2016 .2 Disponível em: $<$ http://www.marketsandmarkets.com/Market-Reports/biosurfactants-market493.html>. Acesso em: 28 jan 2017.

MASUDA, C. A. et al. Phosphoglucomutase is an in vivo lithium target in yeast. The Journal of Biological Chemistry, v. 276, n. 41, p. 37794-37801, 2001.

MIEYAL, J. J.; SIMON, M.; ABELES, R. H. Mechanism of action of sucrose phosphorylase. 3. The reaction with water and other alcohols. Journal of Biology and Chemistry, v. 247, n. 2, p. 532-42, 1972. 
MÜLLER, M. M. et al. Rhamnolipids: Next generation surfactants?. Journal of Biotechnology, v. 162, n. 4, p. 366-380, 2012.

MULLIGAN, C. N.; YONG, R. N.; GIBBS, B. F. Surfactant-enhanced remediation of contaminated soil: a review. Engineering Geology, v. 60, n. 1-4, p. 371-380, 2001.

MULLIGAN, C. N. Environmental applications for biosurfactants. Environmental Pollution, v. 133, n. 2, p. 183-198, 2005.

MUMBERG, D. et al. Yeast vectors for the controlled expression of heterologous proteins in different genetic backgrounds. Gene, v. 156, p. 119-122, 1995.

MWESIGYE, P. K.; BARFORD, J. P. Mechanism of sucrose utilization by Saccharomyces cerevisiae. Journal of General and Applied Microbiology, v. 42, 1996.

NAUMOV, G. I. et al. Polymeric SUC genes in natural populations of Saccharomyces cerevisiae. FEMS Microbiology Letters, v. 135, n. 1, p. 31-5, 1996.

NOH, N. A.; SALLEH, S. M.; YAHYA, A. R. Enhanced rhamnolipid production by Pseudomonas aeruginosa USM-AR2 via fed-batch cultivation based on maximum substrate uptake rate. Letters on Applied Microbiology, v. 58, n. 6, p. 617-623, 2014.

PAULINO, B. N. et al. Current status in biotechnological production and applications of glycolipid biosurfactants. Applied Microbiology and Biotechnology, v. 100, n. 24, p.10265-10293, 2016.

PORNSUNTHORNTAWEE, O.; WONGPANIT, P.; RUJIRAVANIT, R. Rhamnolipid Biosurfactants: Production and their Potential in Environmental Biotechnology. In: SEN, R. (Ed.) Biosurfactants. Nova lorque: Springer-Verlag, 2010. p. 211-221. 
RÄBINÄ, J. et al. Analysis of nucleotide sugars from cell lysates by ion-pair solid-phase extraction and reversed-phase high-performance liquid chromatography. Glycoconjugate Journal, v. 18, p. 799-805, 2001.

REIS, R. S. et al. Gene regulation of rhamnolipid production in Pseudomonas aeruginosa: a review. Bioresource technology, v. 102, n. 11, p. 6377-84, 2011.

REIS, R. S. et al. Biosurfactants: Production and Applications. In: CHAMY, R.; ROSENKRANZ, F. (Ed.) Biodegradation: Life of Science. InTech, 2013. p. 3161.

RODRIGUES, L. et al. Biosurfactants: potential applications in medicine. The Journal of antimicrobial chemotherapy, v. 57, n. 4, p. 609-618, 2006.

SCHMIDBERGER, A. et al. Expression of genes involved in rhamnolipid synthesis in Pseudomonas aeruginosa PAO1 in a bioreactor cultivation. Applied Microbiology and Biotechnology, v. 97, n. 13, p. 5779-91, 2013.

SEKHON RANDHAWA, K. K.; RAHMAN, P. K. S. M. Rhamnolipid biosurfactantspast, present, and future scenario of global market. Frontiers in Microbiology, v. 5, p. 454, 2014.

SHA, S. et al. Development of a colorimetric assay and kinetic analysis for Mycobacterium tuberculosis D-glucose-1-phosphate thymidylyltransferase. Journal of Biomolecular Screening, v. 17, n. 2, p. 252-7, 2012.

SHORT, J.S. et al. Lambda ZAP: a bacteriophage lambda expression vector with in vivo excision properties. Nucleic Acid Research. v. 16, n. 15, p. 7583-7600, 1988.

SYLDATK, C. et al. Chemical and physical characterization of four interfacial-active rhamnolipids from Pseudomonas spec. DSM 2874 grown on n-alkanes. Zeitschrift fur Naturforschung Section C, v. 40, n. 1-2, p. 51-60, 1985. 
TANG, X.; LEE, J.; CHEN, W. N. Engineering the fatty acid metabolic pathway in Saccharomyces cerevisiae for advanced biofuel production. Metabolic Engineering Communications, v. 2, p. 58-66, 2015.

TURNOCK, D. C.; FERGUSON, M. A. Sugar nucleotide pools of Trypanosoma brucei, Trypanosoma cruzi, and Leishmania major. Eukaryotic Cell, v. 6, n. 8, p. 1450-63, 2007.

VAN BOGAERT, I. N. A. et al. Microbial production and application of sophorolipids. Applied microbiology and biotechnology, v. 76, n. 1, p. 23-34, 2007.

WANG, Q. et al. Engineering bacteria for production of rhamnolipid as an agent for enhanced oil recovery. Biotechnology and Bioengineering, v. 98, n. 4, p. 842-53, 2007.

WITTGENS, A. et al. Growth independent rhamnolipid production from glucose using the non-pathogenic Pseudomonas putida. Microbial Cell Factories, v. 10, p. 80 , 2011. 